DOE/ID-22216

Prepared in cooperation with the U.S. Department of Energy

\title{
Assessing Controls on Perched Saturated Zones Beneath the Idaho Nuclear Technology and Engineering Center, Idaho
}

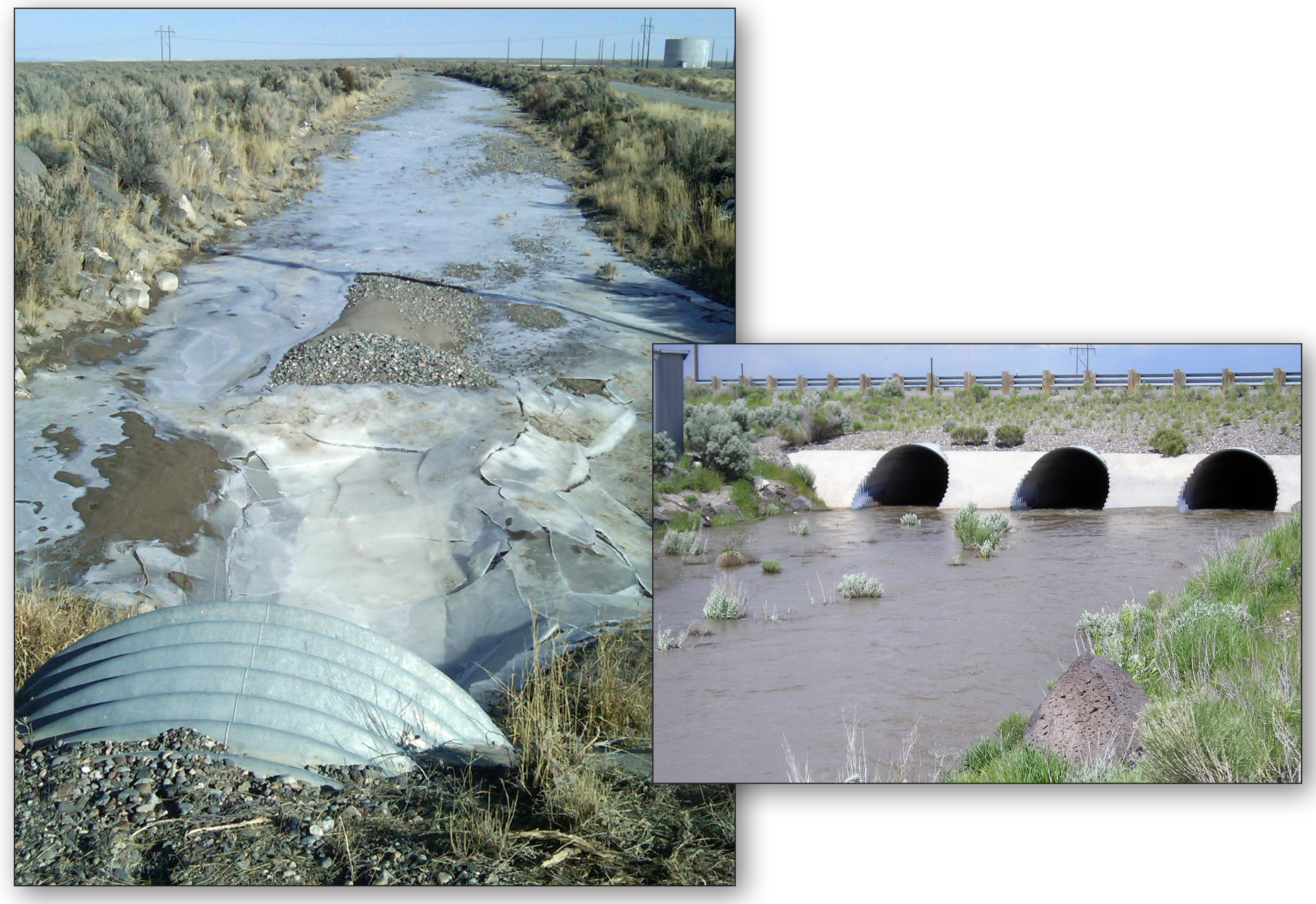

Scientific Investigations Report 2011-5222 
Cover: Photographs of the Big Lost River (left) looking towards the Idaho Nuclear Technology and Engineering Center (courtesy of Dave Eaton, CH2M Hill) and (right) at Lincoln Boulevard Gage (courtesy of USGS INL Project Office). 


\section{Assessing Controls on Perched Saturated Zones Beneath the Idaho Nuclear Technology and Engineering Center, Idaho}

By Benjamin B. Mirus, Kim S. Perkins, and John R. Nimmo

Prepared in cooperation with the U.S. Department of Energy

Scientific Investigations Report 2011-5222 


\section{U.S. Department of the Interior \\ KEN SALAZAR, Secretary}

U.S. Geological Survey
Marcia K. McNutt, Director

U.S. Geological Survey, Reston, Virginia: 2011

This report and any updates to it are available online at: http://pubs.usgs.gov/sir/2011/5222

For more information on the USGS - the Federal source for science about the Earth, its natural and living resources, natural hazards, and the environment, visit http://www.usgs.gov or call 1-888-ASK-USGS

For an overview of USGS information products, including maps, imagery, and publications, visit http://www.usgs.gov/pubprod

To order this and other USGS information products, visit http://store.usgs.gov

Any use of trade, product, or firm names is for descriptive purposes only and does not imply endorsement by the U.S. Government.

Although this report is in the public domain, permission must be secured from the individual copyright owners to reproduce any copyrighted materials contained within this report.

Suggested Citation:

Mirus, B.B., Perkins, K.S., and Nimmo, J.R., 2011, Assessing controls on perched saturated zones beneath the Idaho Nuclear Technology and Engineering Center, Idaho: U.S. Geological Survey Scientific Investigations Report 2011-5222 (DOE/ID-22216), 20 p. 


\section{Contents}

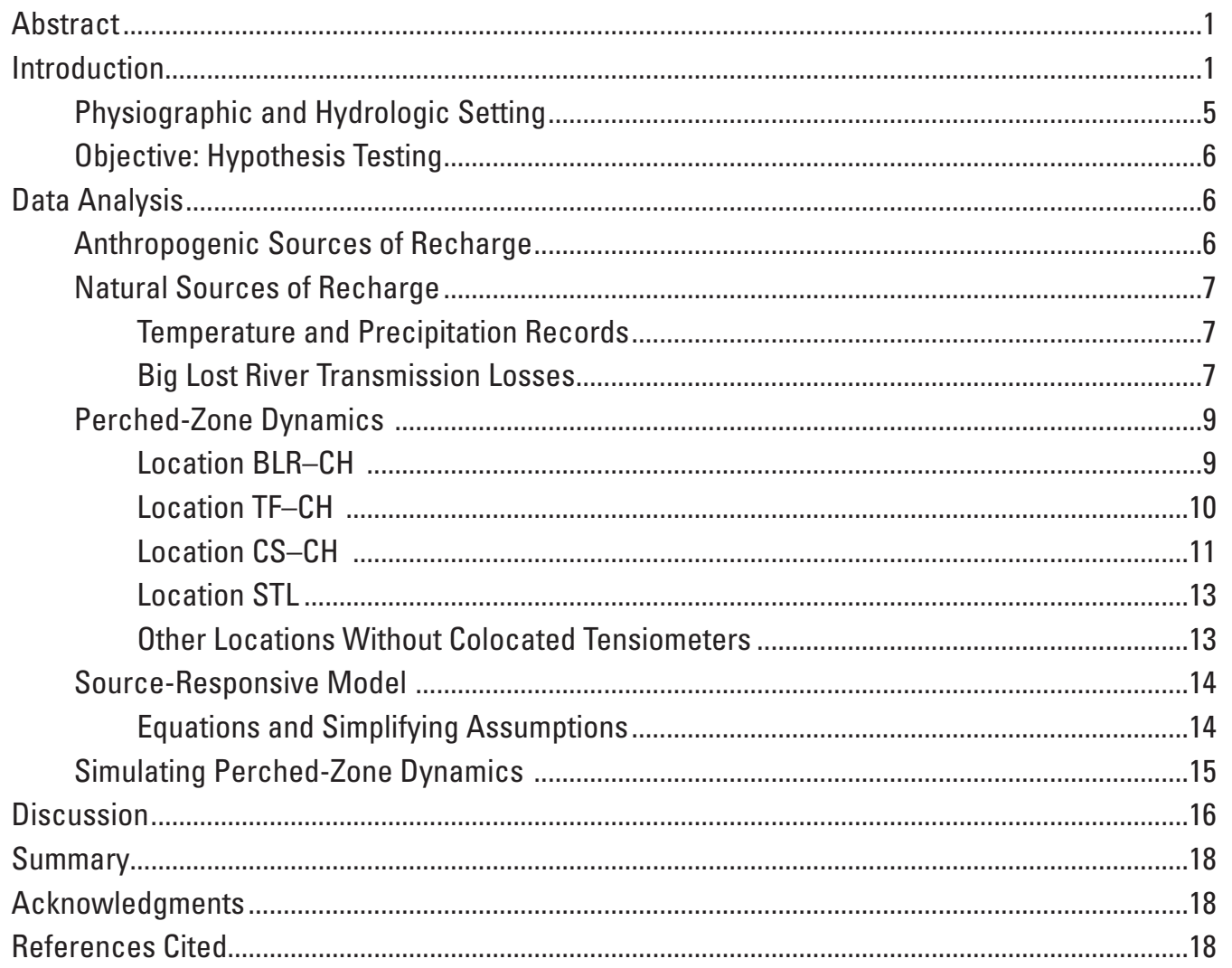

\section{Figures}

1. Map showing location of the Idaho National Laboratory, Idaho, and selected facilities ..........2

2. Map showing the Idaho Nuclear Technology and Engineering Center (INTEC) in relation to the Big Lost River (BLR) and the USGS stream gaging station at Lincoln Boulevard ............3

3. Map showing the monitoring locations within the Idaho Nuclear Technology and Engineering Center (INTEC)

4. Diagram showing the conceptual model of vadose zone flow in the vicinity of the Idaho Nuclear Technology and Engineering Center (INTEC)

5. Graph illustrating the daily climatic records at the Idaho Nuclear Technology and Engineering Center (INTEC) for 2001-2010, including maximum, average, and minimum air temperatures..

6. Graph illustrating the monthly and cumulative precipitation records at the Idaho Nuclear Technology and Engineering Center (INTEC) for 2001-2010

7. Graph showing time series of discharge in the BLR between 1994 and 2009 measured for two USGS gaging stations - the bridge at Lincoln Boulevard and at the diversion dam $15 \mathrm{~km}$ upstream

8. Graph showing perched-zone dynamics in the piezometer and nested tensiometers at location BLR-CH. 
9. Graph showing the discharge hydrograph in the BLR and the corresponding response in the shallow perched zone at BLR-CH during 2005 and 2006.

10. Graph showing perched-zone dynamics in the piezometer and nested tensiometers at location TF-CH.

11. Graph showing perched-zone dynamics in the piezometer and nested tensiometers at location $\mathrm{CS}-\mathrm{CH}$

12. Graph showing the maximum daily air temperature and the corresponding response to snowmelt in the shallow perched zone at location CS-CH for wetter years 2005 and 2006

13. Graph showing perched-zone dynamics in the nested tensiometers at location STL...........12

14. Graph showing hydrologic response dynamics in piezometers screened within the shallow perched zone at locations 33-2, 33-3, 33-4-1, 37-4, 55-06, MW-2, MW-4-2, MW-5-2 and MW-6

15. Graph showing transmission losses along the $15-\mathrm{km}$ reach of the Big Lost River between the two gaging stations in figure 7 and the time series for active area fraction $f(t)$ employed in the source-responsive model

16. Graphs showing observed time series of hydraulic head for the tensiometer and piezometer at BLR-CH with simulated hydraulic heads for two events.

\section{Table}

1. Model performance statistics calculated for the calibration and evaluation period using observed responses from both the tensiometer and piezometer in the shallow perched zone at BLR-CH 


\section{Conversion Factors and Datums}

\begin{tabular}{lll}
\hline \multicolumn{1}{c}{ Multiply } & \multicolumn{1}{c}{ By } & \multicolumn{1}{c}{ To obtain } \\
\hline centimeter $(\mathrm{cm})$ & 0.3937 & inch $(\mathrm{in})$. \\
centimeter of water $(\mathrm{cm}$-water) & 0.01419 & pound per square inch $\left(\mathrm{lb} / \mathrm{in}^{2}\right)$ \\
meter per day $(\mathrm{m} / \mathrm{d})$ & 3.281 & foot per day $(\mathrm{ft} / \mathrm{d})$ \\
cubic meter per second $\left(\mathrm{m}^{3} / \mathrm{s}\right)$ & 35.314 & cubic feet per second $\left(\mathrm{ft}^{3} / \mathrm{s}\right)$ \\
kilometer $(\mathrm{km})$ & 0.6214 & mile $(\mathrm{mi})$ \\
meter $(\mathrm{m})$ & 3.281 & foot $(\mathrm{ft})$ \\
square kilometer $\left(\mathrm{km}^{2}\right)$ & 247.1 & acre \\
square kilometer $\left(\mathrm{km}^{2}\right)$ & 0.3861 & square mile $\left(\mathrm{mi}^{2}\right)$ \\
\hline
\end{tabular}

Temperature in degrees Celsius $\left({ }^{\circ} \mathrm{C}\right)$ may be converted to degrees Fahrenheit $\left({ }^{\circ} \mathrm{F}\right)$ as follows:

$$
{ }^{\circ} \mathrm{F}=\left(1.8 \times{ }^{\circ} \mathrm{C}\right)+32
$$

Vertical coordinate information is referenced to the National Geodetic Vertical Datum of 1929 (NGVD of 1929).

Horizontal coordinate information is referenced to the North American Datum of 1983 (NAD 83).

Altitude, as used in this report, refers to distance above the vertical datum.

\section{Acronyms}

$\begin{array}{ll}\text { ATR } & \text { Advanced Test Reactor } \\ \text { BLR } & \text { Big Lost River } \\ \text { DOE } & \text { Department of Energy } \\ \text { ESRP } & \text { Eastern Snake River Plain } \\ \text { ICPP } & \text { Idaho Chemical Processing Plant } \\ \text { INL } & \text { Idaho National Laboratory } \\ \text { INTEC } & \text { Idaho Nuclear Technology and Engineering Center } \\ \text { ROD } & \text { Record of Decision } \\ \text { RWMC } & \text { Radioactive Waste Management Complex } \\ \text { SRFM } & \text { Source-Responsive Fluxes Model } \\ \text { TAN } & \text { Test Area North } \\ \text { TRA } & \text { Test Reactor Area } \\ \text { USGS } & \text { U.S. Geological Survey }\end{array}$


This page left intentionally blank 


\title{
Assessing Controls on Perched Saturated Zones Beneath the Idaho Nuclear Technology and Engineering Center, Idaho
}

\author{
By Benjamin B. Mirus, Kim S. Perkins, and John R. Nimmo
}

\section{Abstract}

Waste byproducts associated with operations at the Idaho Nuclear Technology and Engineering Center (INTEC) have the potential to contaminate the eastern Snake River Plain (ESRP) aquifer. Recharge to the ESRP aquifer is controlled largely by the alternating stratigraphy of fractured volcanic rocks and sedimentary interbeds within the overlying vadose zone and by the availability of water at the surface. Beneath the INTEC facilities, localized zones of saturation perched on the sedimentary interbeds are of particular concern because they may facilitate accelerated transport of contaminants. The sources and timing of natural and anthropogenic recharge to the perched zones are poorly understood. Simple approaches for quantitative characterization of this complex, variably saturated flow system are needed to assess potential scenarios for contaminant transport under alternative remediation strategies. During 2009-2011, the U.S. Geological Survey (USGS), in cooperation with the U.S. Department of Energy, employed data analysis and numerical simulations with a recently developed model of preferential flow to evaluate the sources and quantity of recharge to the perched zones. Piezometer, tensiometer, temperature, precipitation, and stream-discharge data were analyzed, with particular focus on the possibility of contributions to the perched zones from snowmelt and flow in the neighboring Big Lost River (BLR). Analysis of the timing and magnitude of subsurface dynamics indicate that streamflow provides local recharge to the shallow, intermediate, and deep perched saturated zones within $150 \mathrm{~m}$ of the BLR; at greater distances from the BLR the influence of streamflow on recharge is unclear. Perched water-level dynamics in most wells analyzed are consistent with findings from previous geochemical analyses, which suggest that a combination of annual snowmelt and anthropogenic sources (for example, leaky pipes and drainage ditches) contribute to recharge of shallow and intermediate perched zones throughout much of INTEC. The source-responsive fluxes model was parameterized to simulate recharge via preferential flow associated with intermittent episodes of streamflow in the BLR. The simulations correspond reasonably well to the observed hydrologic response within the shallow perched zone. Good model performance indicates that source-responsive flow through a limited number of connected fractures contributes substantially to the perched-zone dynamics. The agreement between simulated and observed perched-zone dynamics suggest that the source-responsive fluxes model can provide a valuable tool for quantifying rapid preferential flow processes that may result from different land management scenarios.

\section{Introduction}

The Idaho National Laboratory (INL) was established in 1949 under the U.S. Atomic Energy Commission, now the U.S. Department of Energy (DOE), for nuclear energy research. INL occupies about $2,300 \mathrm{~km} 2$ of the west-central part of the eastern Snake River Plain (ESRP) (fig. 1). The site hosts several facilities, of which at least four have been used to generate, store, or dispose of radioactive, organic, and inorganic wastes. These facilities include the (1) Radioactive Waste Management Complex (RWMC); (2) Advanced Test Reactor (ATR), formerly known as the Test Reactor Area (TRA); (3) Test Area North (TAN); and (4) Idaho Nuclear Technology and Engineering Center (INTEC); formerly known as the Idaho Chemical Processing Plant (ICPP). Operations at these facilities have introduced contaminants into the subsurface. At the INTEC facility (figs. 2, 3) groundwater contaminants of concern include (DOE-ID, 2007a): strontium-90; technetium-99; tritium (hydrogen-3), iodine-129, cesium-137, uranium $(233 / 234,235$, and 238$)$, plutonium (238 and 239/240), americium-241, mercury, and nitrate. The continued spread of these contaminants throughout the subsurface poses a threat to the water quality in the underlying ESRP aquifer (Department of Energy, 2004, 2007b). For example, increased concentrations of I-129 observed in the aquifer in 2007 (Bartholomay, 2009) suggest that processes in the unsaturated zone are moving contaminants from the perched zones rapidly downward. Methods for quantitative characterization of the complex, variably saturated flow system beneath INTEC are needed to assess potential scenarios for contaminant transport and inform regulatory decisions. The following sections provide the physiographic and hydrologic setting at INTEC and describe the objectives of the present study related to improving quantitative characterization of the complex vadose-zone flow system. 


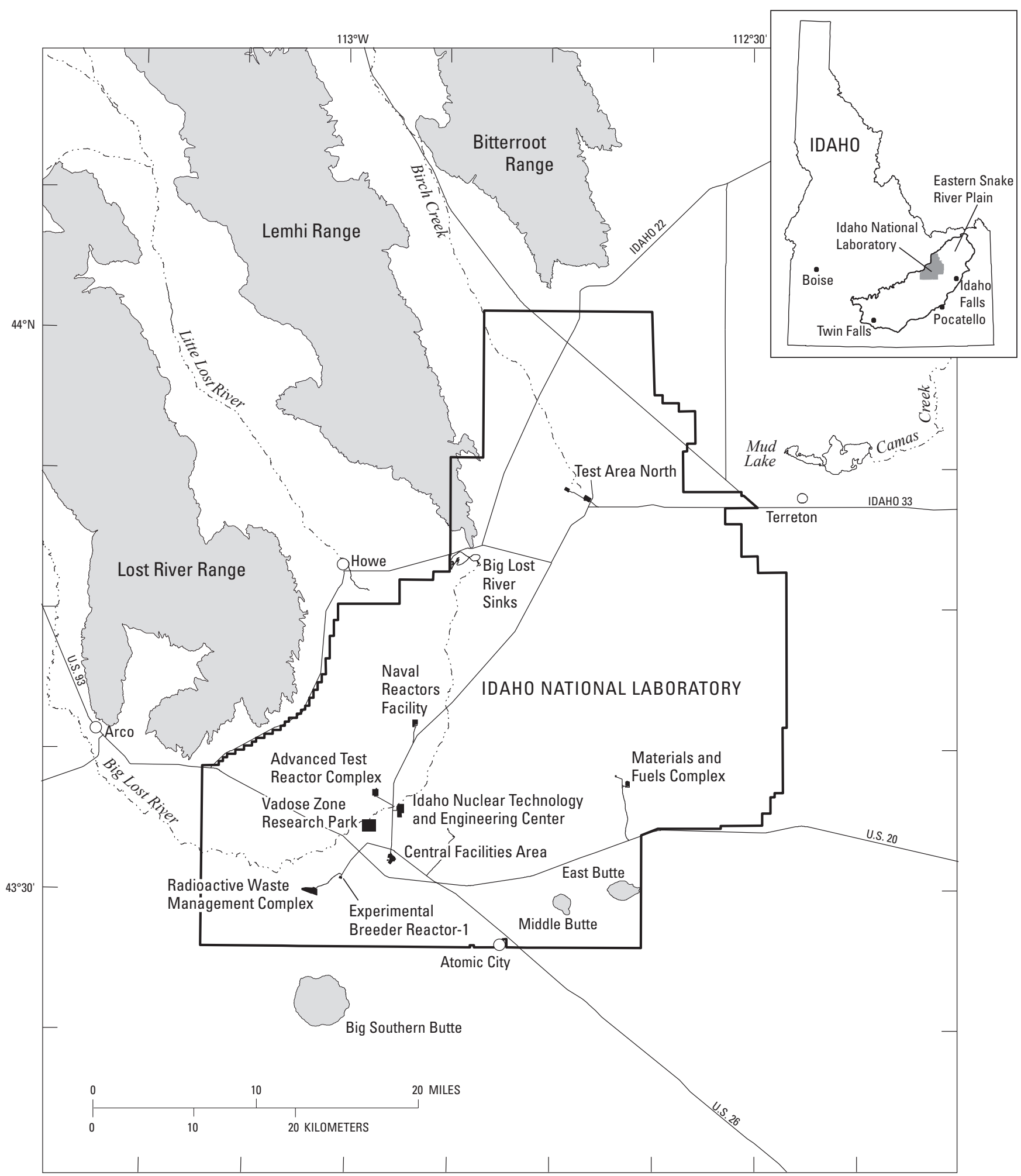

Base from U.S. Geological Survey, 1:100,000, Arco quadrangle, 1989, Blackfoot quadrangle, 1997, Borah Peak quadrangle, 1989, Circular Butte quadrangle, 1980, Craters of the Moon quadrangle, 1978, and Dubois quadrangle, 1983

Figure 1. Location of the Idaho National Laboratory, Idaho, and selected facilities. 


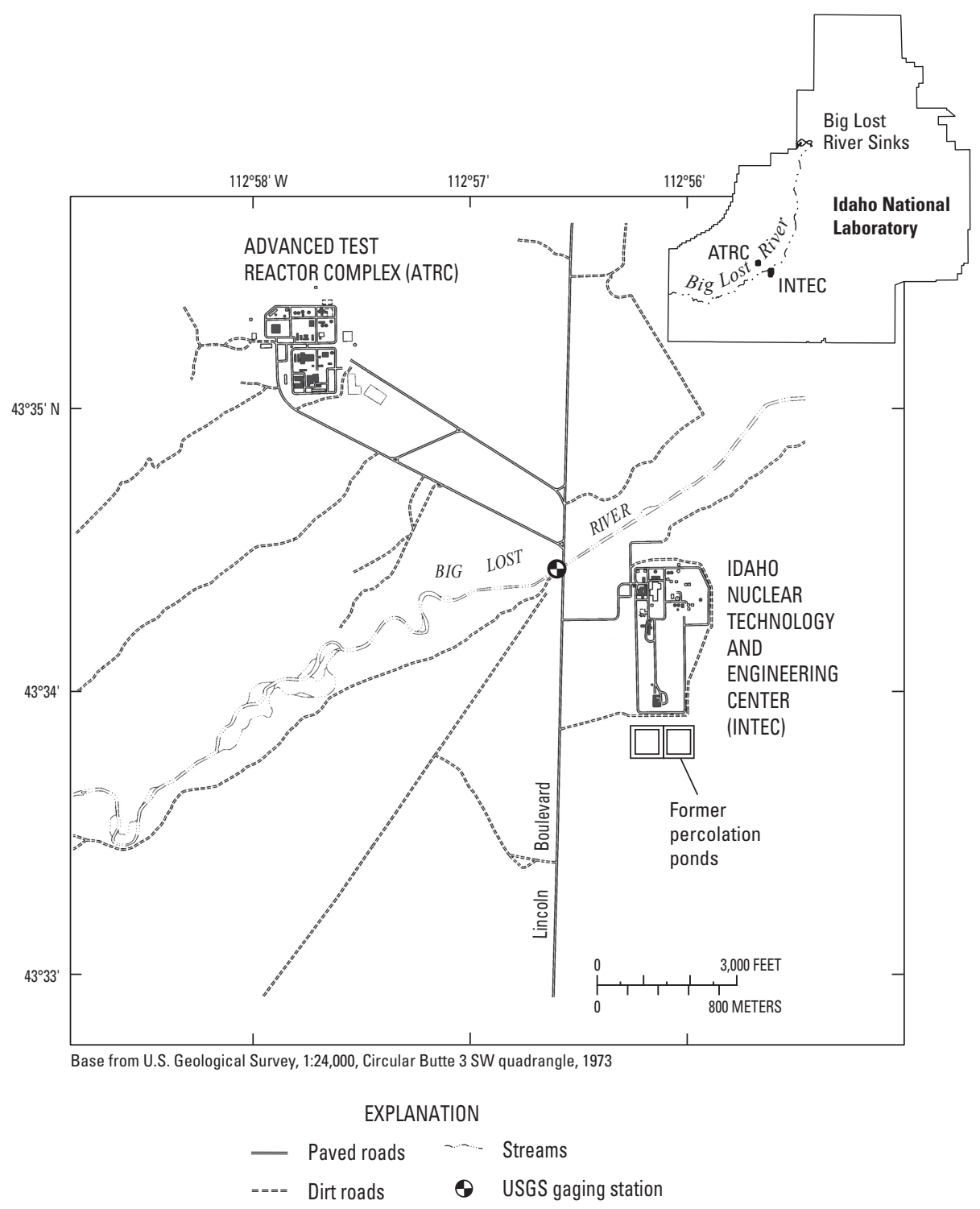

Figure 2. Location of the Idaho Nuclear Technology and Engineering Center (INTEC) in relation to the Big Lost River (BLR) and the USGS stream gaging station at Lincoln Boulevard. 


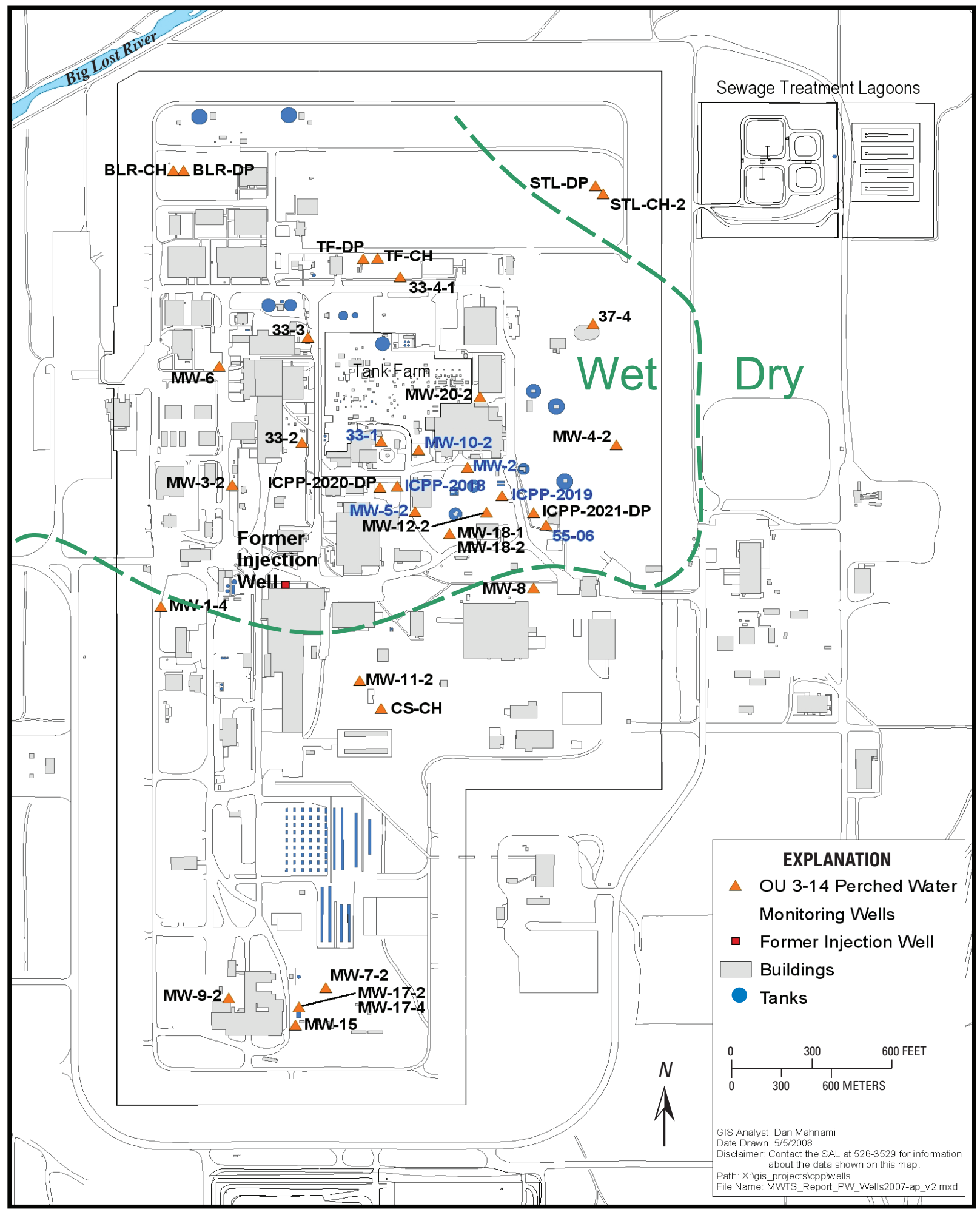

Figure 3. Location of the monitoring locations within the Idaho Nuclear Technology and Engineering Center (INTEC). The approximate extent of the northern perched zone is marked by the dashed green line and annotated wet and dry. 


\section{Physiographic and Hydrologic Setting}

The ESRP lies within a northeast-trending basin, approximately $320 \mathrm{~km}$ long and 80 to $110 \mathrm{~km}$ wide, which slopes gently to the southwest and is bordered on the northwest and southeast by the ends of northwest-trending mountain ranges. The ESRP is underlain by interbedded volcanic and sedimentary layers that extend as much as $3,000 \mathrm{~m}$ below the land surface. The sedimentary interbeds are the products of quiet intervals between volcanic eruptions and are of fluvial, eolian, and lacustrine origin, with large amounts of sand, silt, and clay. Volcanic units composed primarily of basalt flows, welded ash flows, and rhyolite, range from vesicular to massive with either horizontal or vertical fracture patterns. Near the INTEC, boreholes drilled to 200-m depths penetrate a sequence of 23 basalt-flow groups and 15 to 20 sedimentary interbeds (Anderson, 1991). The surficial sediments near INTEC consist of gravelly alluvium, range from 2 to $20 \mathrm{~m}$ thick, and are thickest to the northwest (Anderson and others, 1996).

The climate of the ESRP is semiarid, and the average annual precipitation is $0.22 \mathrm{~m}$ (Department of Energy, 1989). Parts of the ESRP aquifer underlie INL, and depths to the regional water table range from $61 \mathrm{~m}$ in the north to about $274 \mathrm{~m}$ in the south and approximately $145 \mathrm{~m}$ in the region below INTEC (Davis, 2010). The predominant direction of groundwater flow within the aquifer is from northeast to southwest. Recharge is primarily from (Hackett and others, 1986): irrigation water diversions from streams; precipitation and snowmelt; underflow from tributary-valley streams; and seepage from surface water bodies.

Recharge fluxes to the ESRP aquifer are controlled largely by the alternating stratigraphy of fractured volcanic rocks and sedimentary interbeds within the overlying vadose zone (Department of Energy, 2004). The fractured rocks facilitate rapid preferential flow and transport downward through the vadose zone, whereas the lower permeability interbeds impede vertical fluxes (fig. 4). Directly beneath the INTEC facilities, shallow zones of perched saturation have developed on top of the sedimentary interbeds. These perched zones are of particular concern because they may accelerate transport of contaminants through the vadose zone by promoting lateral flow, which allows recharge to bypass these horizontally discontinuous interbeds by connecting otherwise disconnected vertical fractures within the basalt (fig. 4A).

The persistence of perched saturation observed in the monitoring wells and tensiometers below INTEC (fig. 3), along with the apparent absence of perched zones in other monitored regions of INL, suggests that the cumulative effect of anthropogenic sources of water associated with operations at INTEC is of primary importance. Lawn irrigation,

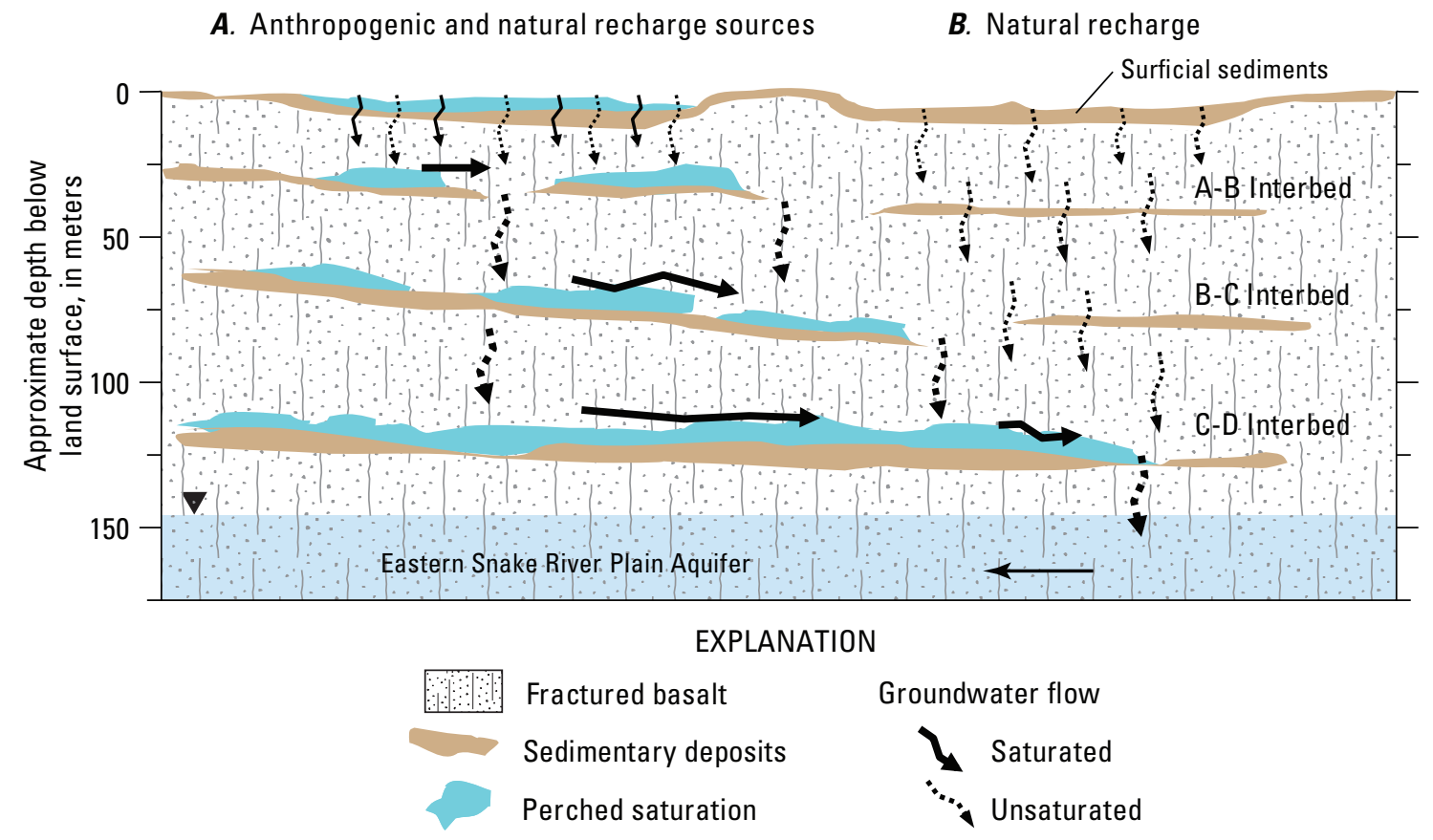

Figure 4. Conceptual model of vadose zone flow in the vicinity of the Idaho Nuclear Technology and Engineering Center (INTEC). With anthropogenic sources of recharge, localized perched saturation develops, facilitating lateral flow around discontinuous interbeds, which promotes rapid vertical fluxes of contaminated water along connected fracture networks $(A)$. Without anthropogenic sources of recharge, no perched saturation develops and unsaturated flow is strictly vertical, such that downward migration of contaminants is impeded by the lowpermeability sedimentary interbeds $(B)$. 
leaky pipes and storage tanks, unlined drainage ditches and detention ponds, as well as other surface water storage, are known sources of recharge to the perched zones (Department of Energy, 2005a,b,c, 2006). However, the contributions of natural sources such as precipitation and seepage from the neighboring Big Lost River (BLR) may also be a factor (Department of Energy, 2006). Previous investigations using geochemical signatures (Department of Energy, 2005d) and relative soil moisture indexes (Department of Energy, 2006) suggest that infiltration of rainfall and snowmelt contributes to perched-zone recharge more than flow in the BLR. Unfortunately, there was no flow in the BLR during 2003 and 2004 when water was sampled for geochemical analysis, and episodic streamflow in the BLR corresponds to periods when soil moisture is relatively high. As a result it is difficult to quantitatively evaluate the contributions of transmission losses from riverbed seepage along the BLR to the perched zones.

Previous efforts at characterizing the unsaturated zone at INL by the U.S. Geological Survey (USGS) have focused on the hydraulic properties of the sedimentary interbeds (Perkins and Nimmo, 2000; Perkins, 2003; Winfield, 2003) and development of property-transfer models (Winfield, 2005; Perkins and Winfield, 2007; Perkins, 2008), which together provide a firm foundation for large-scale simulation of water and contaminant transport using traditional numerical models based on Richards' equation. However, tracer experiments conducted at INL indicate that flow via preferential pathways is capable of rapid transport that cannot be represented adequately using conventional diffuse unsaturated flow theory (Nimmo and others, 2002). In the work presented here, we evaluate the potential for preferential flow as it relates to the perched zones beneath the INTEC facility using a combination of data analysis and numerical simulation.

\section{Objective: Hypothesis Testing}

The overarching objective of this study is to improve quantitative characterization of the hydrologic controls on contaminant transport within the complex vadose zone beneath INTEC. The USGS, in cooperation with the U.S. Department of Energy, aims to achieve this objective by exploring the suitability of the recently developed Source-Responsive Model for unsaturated-zone preferential flow (Nimmo, 2007, 2010). Two major hypotheses are investigated related to the potential sources of recharge to the perched zones beneath INTEC:

1. Transmission losses from the BLR and natural sources of recharge have negligible impact on the perched water throughout INTEC.

2. Source-responsive theory for unsaturated-zone preferential flow can be used for quantitatively characterizing the observed perched-zone dynamics.

These two hypotheses relate to the conceptual model of variably saturated flow illustrated in figure 4 . The first hypothesis is tested through comparative analysis of subsurface hydrologic-response data and the timing of release of potential sources of recharge to the perched zones. The second hypothesis is tested by comparing observed tensiometer and piezometer responses to simulation results from the Source-Responsive Fluxes Model (Nimmo, 2010). It should be noted that not all the data available were suitable for application of the SourceResponsive Fluxes Model (SRFM), so the data analysis contributed substantially to testing of the second hypothesis through identification of appropriate data for model parameterization and evaluation. The knowledge gained through the hypothesis testing presented here will contribute to developing a robust model of contaminant transport through the vadose zone flow at INTEC and elsewhere in the INL.

\section{Data Analysis}

Previous characterization of the subsurface beneath INTEC has identified three discontinuous zones of perched saturation, each occurring at effective permeability contrasts between the fractured volcanic rocks and underlying sedimentary interbeds (Department of Energy, 2007a,c). The land surface at INTEC is approximately $1,499 \mathrm{~m}$ above mean sea level. The shallowest perched zone is at approximately $26-46 \mathrm{~m}$ below land surface (bls), perched on the A-B interbed. The intermediate perched zone is at approximately 57-102 m bls, perched on the B-C interbed. The deepest perched zone is at approximately $110-134 \mathrm{~m}$ bls, perched on the $\mathrm{C}-\mathrm{D}$ interbed; it appears to extend over a greater region than the intermediate and shallow zones. Continuous and intermittent monitoring of nested sets of tensiometers and piezometers within each perched zone has contributed to important insights regarding the subsurface dynamics below INTEC (Department of Energy, 2004, 2005a,b,c,d, 2006, $2007 \mathrm{a}, \mathrm{b}, \mathrm{c})$. The distributed network of monitoring locations (fig. 3) with observed records between 2001 and 2009 facilitates the comparative analysis of the subsurface hydrologic response and the timing of release of known and potential sources of recharge presented here. The following sections discuss the anthropogenic and natural sources of recharge and examine the subsurface dynamics in relation to the timing of release of recharge sources.

\section{Anthropogenic Sources of Recharge}

The large wastewater service ponds at the southern border of the INTEC facility (fig. 2) were substantial anthropogenic sources of recharge. These ponds were withdrawn from operation in August 2002, which led to declines in perched water levels in the southern portion of INTEC (Department of Energy, 2005a,b,c). Success of this operational change in reducing perched saturation led to the identification and elimination of several other anthropogenic sources of recharge in the northern and central areas of INTEC (Department of Energy, $2007 \mathrm{a}, \mathrm{b}, \mathrm{c})$. The sewage treatment lagoons in the northeast 
corner (fig. 3) were withdrawn from operation in December 2004. Irrigation of the lawns distributed around the facility ceased in October 2005. A small brine pit in the central part of the facility near the tank farms (see fig. 3) was withdrawn from operation in December 2007. Water lines for fire control were repaired in October of 2007, leading to observed declines in piezometers 33-4-1 and TF-CH. Leaky hydrants repaired in February 2008 led to the declines in the shallow perched zone observed in wells MW-6 and MW-15. Several other sources of anthropogenic recharge have been identified with measurements from monitoring wells throughout INTEC (Department of Energy, 2011). Despite the elimination of these anthropogenic sources of recharge, the persistence of perched saturation in the northern half of INTEC and the associated plumes of contaminants in the subsurface (DOE-ID, 2007b) demonstrate the need to improve understanding of the controls on perched saturation beyond the role of anthropogenic sources.

\section{Natural Sources of Recharge}

Two sources of natural recharge that contribute to the perched saturated zones beneath INTEC are analyzed here. First, the timing and potential magnitude of snowmelt are assessed using temperature and precipitation records. Second, the transmission losses in the BLR are calculated using streamflow records from two USGS gaging stations. The analyses emphasize the period between 2001 and 2009, when subsurface hydrologic response was monitored at INTEC.

\section{Temperature and Precipitation Records}

Facilities management at INTEC removes snow from roads and paved surfaces, depositing it in piles at various locations (Dean Shanklin, oral commun., 2011). This practice may result in focused recharge that could enhance preferential flow in some areas. The daily climatic records for INTEC, with maximum, average, and minimum daily air temperatures for the period between January 2001 and May 2010, are shown in figure 5 . The monthly and cumulative precipitation for the period between January 2001 and May 2010 are shown in figure 6 . Temperature records in figure 5 display a consistent annual cycle reaching lows of below $-20^{\circ} \mathrm{C}$ in the winter months and highs between 30 and $40^{\circ} \mathrm{C}$ in the summer months. Examination of the hyetographs shown in figure 6 reveals that 2005, 2006, and 2009 were wet years, with particularly high cumulative precipitation during the winter and spring months. Assuming that much of the precipitation in winter months occurs as snow, the spring thaw is likely to occur when air temperatures consistently rise above freezing $\left(0^{\circ} \mathrm{C}\right)$. Thus, although the exact timing and magnitude of snowmelt are difficult to quantify with the available information, the records shown in figures 5 and 6 suggest that subsurface response to a snowmelt-driven recharge would begin in March, which corresponds to local observations (Roy Bartholomay, oral commun., 2011).

\section{Big Lost River Transmission Losses}

Within the INL boundaries, the BLR flows intermittently from southwest to northeast (fig. 1) and cuts across the northeastern edge of the INTEC facilities (figs. 2, 3). The proximity of the BLR to waste-disposal and storage facilities prompted the construction of a diversion system in 1958, which was designed to reduce the threat of flooding (Barraclough and others, 1967). During high-flow periods (discharge above $17 \mathrm{~m}^{3} / \mathrm{s}$ ), excess flow is diverted to topographic depressions

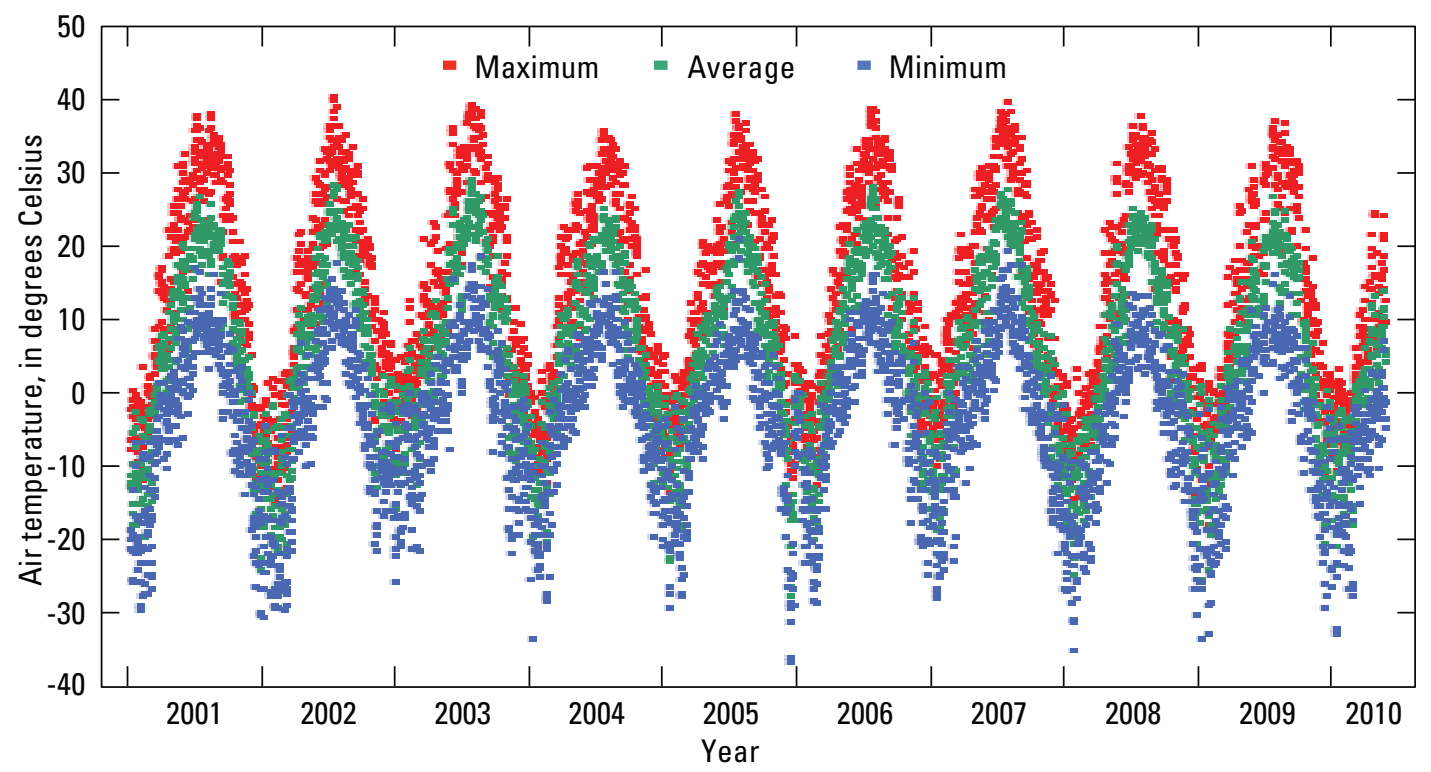

Figure 5. Daily climatic records at the Idaho Nuclear Technology and Engineering Center (INTEC) for 2001-2010, including maximum, average, and minimum air temperatures. 


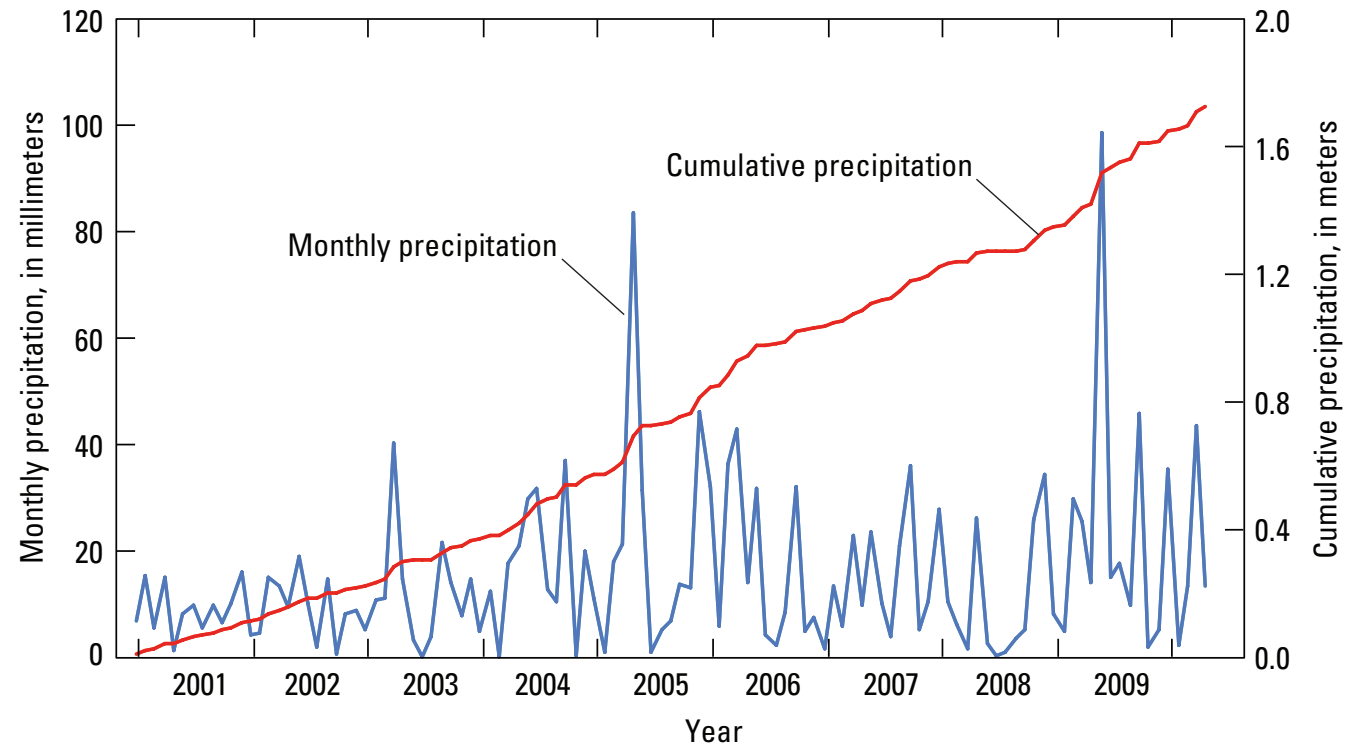

Figure 6. Monthly and cumulative precipitation records at the Idaho Nuclear Technology and Engineering Center (INTEC) for 2001-2010.

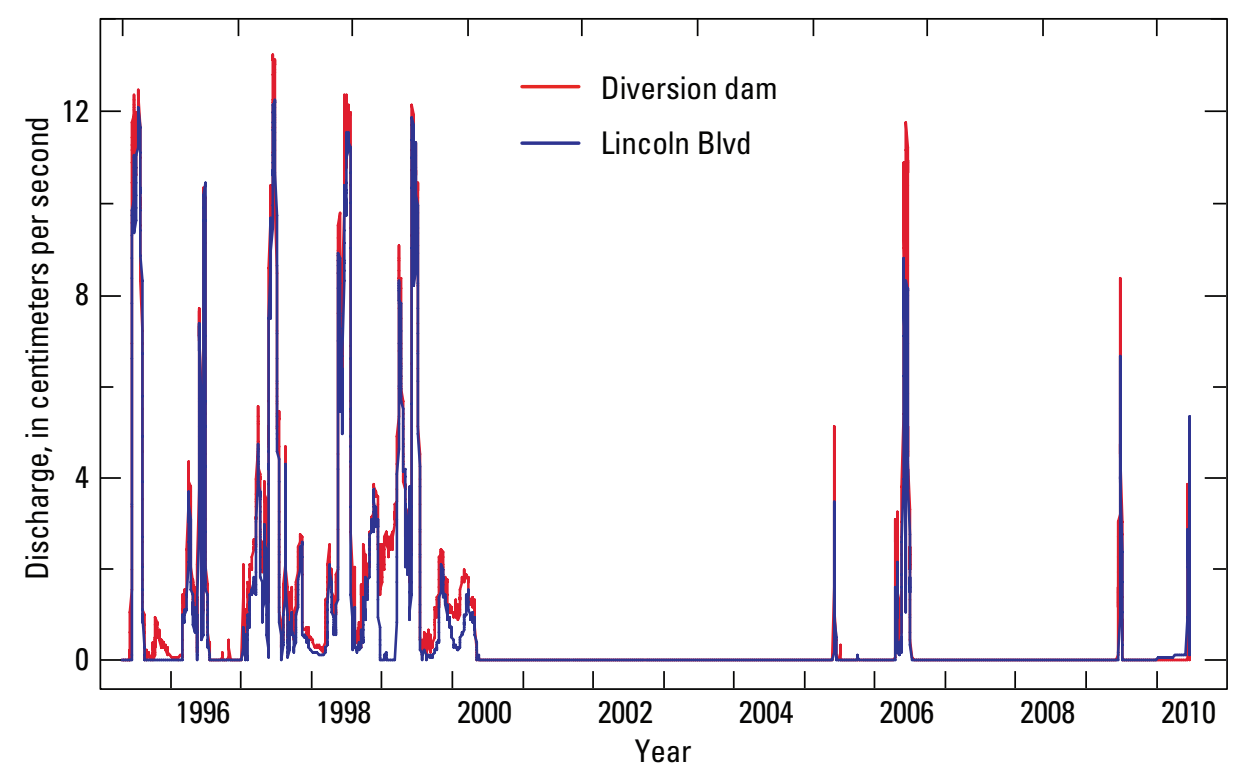

Figure 7. Time series of discharge in the BLR between 1994 and 2009 measured for two USGS gaging stations- - the bridge at Lincoln Boulevard and at the diversion dam $15 \mathrm{~km}$ upstream. 
(referred to as spreading areas) approximately $15 \mathrm{~km}$ southwest of INTEC, with flow continuing in the main channel. The BLR is a losing stream for the reach cutting through INL; transmission losses during periods of flow are likely to contribute to the perched water underlying the INTEC facilities. The hydrographs in figure 7 show daily discharge from 1994 to 2010 in the BLR recorded at two USGS gaging stations: (i) the diversion dam, approximately $15 \mathrm{~km}$ southwest of INTEC, and (ii) the Lincoln boulevard bridge, less than 1 $\mathrm{km}$ northwest of the INTEC facilities (see fig. 2). Perusal of figure 7 shows that the BLR flowed almost continuously from September 1995 through May 2000 and then ceased flowing for several years before flowing again in spring and summer of 2005, 2006, 2009, and 2010. These periods of flow correspond to wet winters (see fig. 6), but do not exceed the threshold for diversion into the spreading areas, which occurred most recently in 1999 (Nimmo and others, 2002). Examination of the differences between the discharges at the two gaging stations (fig. 7) reveals that the transmission losses are somewhat discharge dependent, which echoes findings from previous analysis of older discharge records (Bennett, 1990).

\section{Perched-Zone Dynamics}

Piezometers and colocated nested tensiometers at multiple locations within the northern half of INTEC have been monitored by the INL Waste Area Group 3 contractor between 1996 and 2009, but with several gaps and obvious errors in the observed records. The primary focus of the analysis here is on the shallow perched zone, because it exhibits the most dynamic response to recharge; the intermediate and deep perched zones are given secondary consideration. Monitoring locations with sufficient data for the analysis in this study are shown in figure 3 . Three locations include a piezometer colocated with a set of nested tensiometers: (1) BLR-CH (Big Lost River) is in the northwest corner of the facility, approximately $150 \mathrm{~m}$ south of the BLR, (2) TF-CH (Tank Farms) is in the northern portion of the facility, about $300 \mathrm{~m}$ southeast of the BLR, and (3) CS-CH (Central Structures), is centrally located about $900 \mathrm{~m}$ south of the BLR. The STL monitoring location (Sewage Treatment Lagoons) is $450 \mathrm{~m}$ southeast of the BLR and includes only a set of nested tensiometers with no piezometer. In contrast, several piezometers, all screened within the shallow perched zone, are located throughout the central portion of INTEC without colocated tensiometers, including: 33-2, 33-3, 33-4-1, 37-4, 55-06, MW-2, MW-4-2, MW-5-2, and MW-6.

To address the plausibility of our first hypothesis (see section above on "Objective: Hypothesis Testing"), the dynamics of the vadose zone and shallow perched zone are evaluated to identify correlation between observed hydrologic response and the estimated timing of snowmelt and calculated BLR transmission losses. The subsurface measurements are also examined for the potential occurrence of lateral flow within perched zones. In addition to addressing the first hypothesis, a secondary task in the data analysis is to identify observations with a well-constrained source of recharge and correspondingly clear response in the subsurface. The recharge source and subsurface response are needed to assess the second hypothesis, which is related to the applicability of the SRFM for simulating preferential flow processes at INTEC.

\section{Location BLR-CH}

Figure 8 shows the observed records from July 2001 through July 2009 at the BLR-CH location for the piezometer screened at $37-40 \mathrm{~m}$ bls and nested tensiometers at 10 , $40,50,107$, and $120 \mathrm{~m}$ bls. The gradual rise in the shallow and intermediate perched zones in the winter, spring, and summer of 2004 followed by the sudden decrease in the autumn correspond to neither natural sources of recharge nor reported anthropogenic sources. Clear spikes in the piezometer recorded on June 15, 2005, and June 19, 2006, represent the only rapid increases observed in the piezometer during the period of record $(2.7 \mathrm{~m}$ in one month and $6.4 \mathrm{~m}$ in two months, respectively) and correspond to rapid responses in the tensiometer at $40 \mathrm{~m}$ bls. Figure 9 clearly shows that this sharp rise in the shallow perched zone corresponds to the only two periods of flow in the BLR during the 8 years of observed response records, illustrating that transmission losses contribute substantially to recharge at this location. By comparison, the relatively modest increases in the piezometer water levels recorded in the early spring of both 2007 and 2008 and the simultaneous transition from unsaturated to saturated conditions in the tensiometer at $40 \mathrm{~m}$ bls illustrate the lesser influence of snowmelt at this location.

The fine temporal resolution of the continuous tensiometer measurements makes it possible to illustrate that a rapid subsurface response begins within 5 days after the onset of discharge in the BLR (fig. 9). The stepped response of rapid pressure increase in the tensiometer at $40 \mathrm{~m}$ bls in April and May of 2006 appears to mimic the dual spikes in BLR discharge. This nonuniform response to discharge in the BLR suggests that the discharge-dependent transmission losses exert a threshold-type control on the response in the perched zone.

Examination of figure 8 reveals some apparent measurement errors in the tensiometer at $10 \mathrm{~m}$ bls, but the lack of any response to flow in the BLR in 2005 and 2006 at this depth suggests that recharge from streamflow discharges vertically to some depth below $10 \mathrm{~m}$ before spreading laterally, likely along the A-B interbed. A few days after discharge in the BLR ceases, the shallow perched zone at BLR-CH begins receding, as illustrated by the gradual decline in measured pressureheads in the tensiometer at $40 \mathrm{~m}$ bls and water level in the piezometer at $37-40 \mathrm{~m}$ bls. Following the initial response in the shallow perched zone, there is a damped response in the tensiometer at $50 \mathrm{~m}$ bls, which is located within the A-B interbed (Jeff Forbes, written commun., 2011). This interbed experiences saturated conditions as a result of the BLR flow and then gradually returns to unsaturated conditions over the 


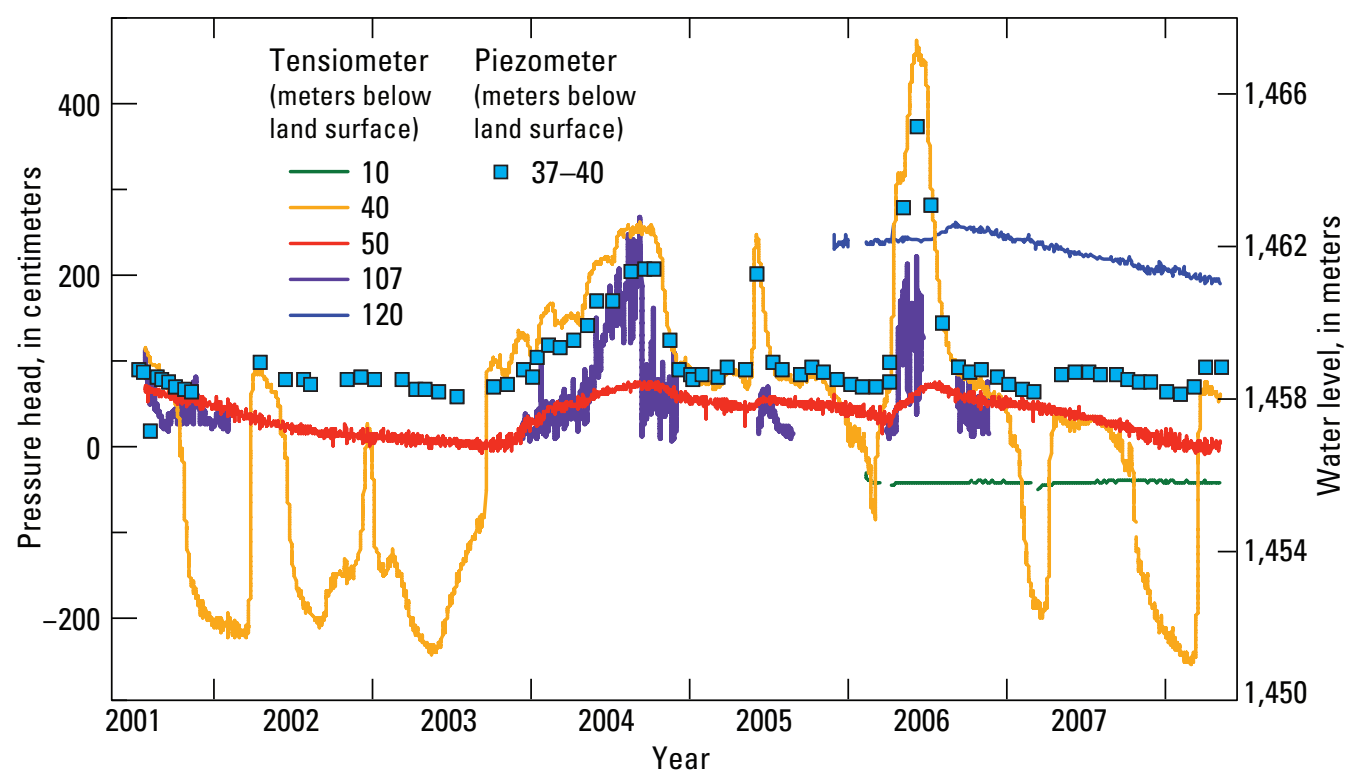

Figure 8. Perched-zone dynamics in the piezometer and nested tensiometers at location BLR-CH (see fig. 3).

subsequent years. Within the intermediate perched zone the measurements from the tensiometer at $107 \mathrm{~m}$ bls are intermittent and noisy, but there appears to be an increase in matric potential following the response in the shallow perched zone. At the tail end of the recession in the shallow perched zone, the tensiometer measurements at $120 \mathrm{~m}$ bls show that the deep perched zone undergoes a lagged response to the streamflow in the BLR. These observations confirm that, although there are other sources of recharge, dynamics in the shallow, intermediate, and deeper perched zones are controlled in large part by the transmission losses from the BLR. The staggered response in tensiometers at 40,50,107, and $120 \mathrm{~m}$ bls in combination with the damping of the responses with depth clearly illustrates the downward propagation of the wetting front.

\section{Location TF-CH}

Figure 10 shows the observed records from January 2002 through December 2008 at the TF-CH location for the piezometer screened at $44-46 \mathrm{~m}$ bls and nested tensiometers at $14,36,48,53$, and $118 \mathrm{~m}$ bls. Examination of figure 10 shows the noisy measurements (for example 2004) and gaps in the records (for example 2003), which are an impediment to comprehensive analysis of the controls on perched-zone dynamics at this location. The rapid response in the saturated zone in 2002 does not correspond to either periods of BLR flow or conditions favoring snowmelt-driven recharge, so this response must be entirely due to anthropogenic recharge sources. The declines in matric potential at $48 \mathrm{~m}$ bls and water level in the piezometer at $44-46 \mathrm{~m}$ bls beginning in late October 2007 correlate with the repair of a nearby water leak in fire-control lines on October 18, 2007.
Figure 10 demonstrates that at this location the near-surface (14 and $36 \mathrm{~m}$ bls) and deeper areas (118 $\mathrm{m}$ bls) remain unsaturated during the period of record and the only saturated regions are between 44 and $53 \mathrm{~m}$ bls. However, the saturation does not necessarily extend across this entire 9-m interval. Whereas the response in the piezometer screened from 44 to $46 \mathrm{~m}$ bls and the tensiometer at $48 \mathrm{~m}$ bls are clearly coupled in 2002 and 2008, the tensiometer at $53 \mathrm{~m}$ depth does not respond. This discrepancy in response at different depths is a reflection of the low-permeability A-B interbed and suggests the presence of an unsaturated region below the tensiometer at $48 \mathrm{~m}$ bls and above the saturated zone recorded by the tensiometer at $53 \mathrm{~m}$ bls. The decoupling between the bottom of

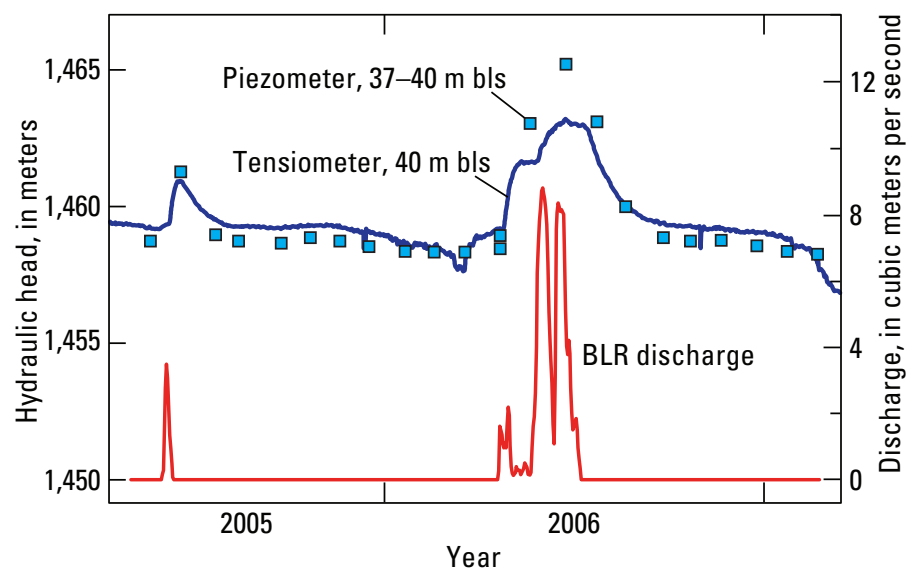

Figure 9. Discharge hydrograph in the BLR and the corresponding response in the shallow perched zone at $\mathrm{BLR}-\mathrm{CH}$ during 2005 and 2006. 


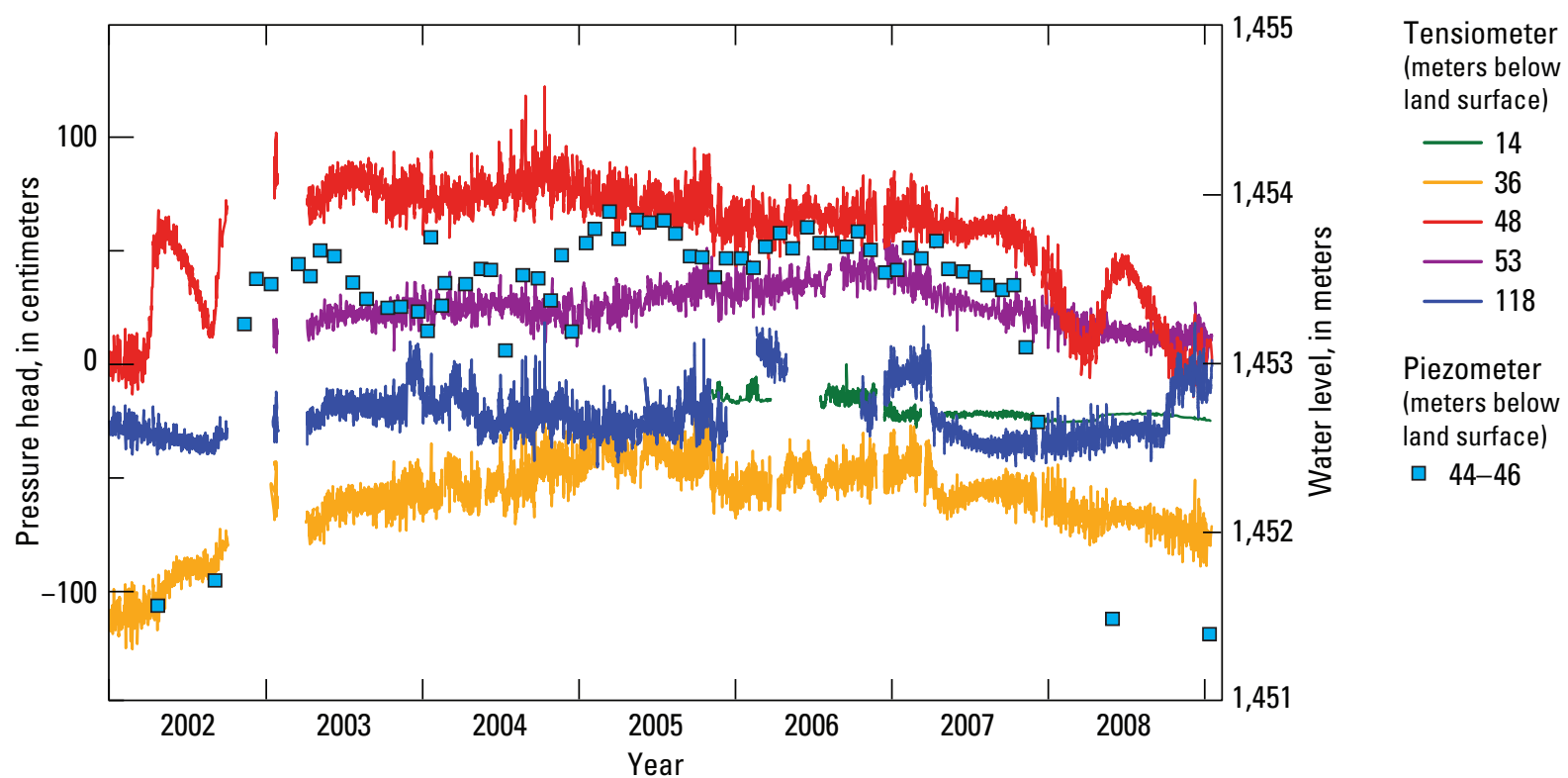

Figure 10. Perched-zone dynamics in the piezometer and nested tensiometers at location TF-CH (see fig. 3).

the shallow perched zone and the upper limit of the intermediate perched zones suggests that recharge to the intermediate zone is via tortuous preferential flow paths. The lack of a clear downward-propagating wetting front at this location highlights the importance of lateral fluxes along the permeability contrast with the sedimentary interbeds. Given the importance of lateral flow paths below the Tank Farms it is unclear whether the persistent elevation in the shallow and intermediate perched zones at this location is maintained as a result of natural recharge or anthropogenic sources, or a combination of both.

\section{Location CS-CH}

Figure 11 shows the observed records from January 2003 through January 2009 at the CS-CH location for the piezometer screened at $57-60 \mathrm{~m}$ bls and nested tensiometers at 13, 37, 47, and $87 \mathrm{~m}$ bls. Examination of figure 11 reveals some noisy and incomplete measurement records, but also some clear responses to recharge episodes. There is a mild response in the tensiometer at $13 \mathrm{~m}$ bls in September of 2003, followed by sharp response in the tensiometer at $37 \mathrm{~m}$ bls in November and then a gradual response in the piezometer at $57-60 \mathrm{~m}$ bls. These responses in the shallow and intermediate perched zones do not correspond to either flow in the BLR or conditions favoring snowmelt and are likely due to anthropogenic recharge or to heavy precipitation in September. Conversely, figure 12 shows that in 2005, 2006, and 2008 the rapid responses in the unsaturated near-surface (tensiometer at $13 \mathrm{~m}$ bls) begin shortly after the maximum daily temperatures rise above freezing. This unsaturated response is followed closely by similar responses in the shallow perched zone (tensiometer at $37 \mathrm{~m}$ bls) and then the intermediate perched zone (piezometer at $57-60 \mathrm{~m}$ bls). This evidence suggests that the initial accretion of the shallow

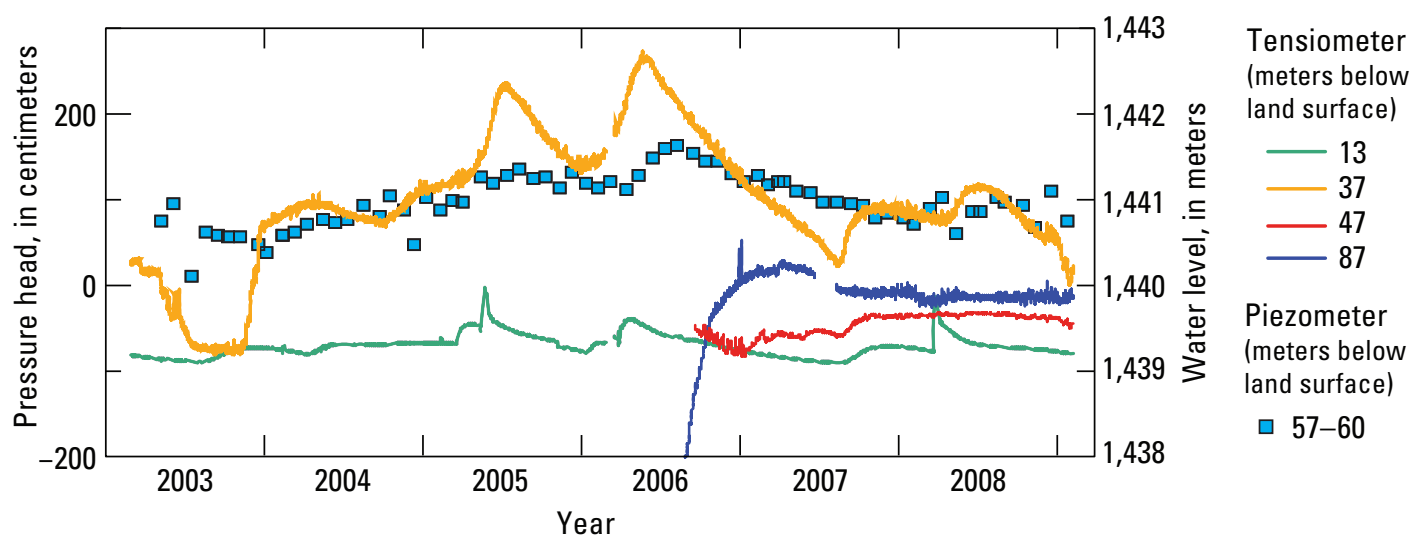

Figure 11. Perched-zone dynamics in the piezometer and nested tensiometers at location CS-CH (see fig. 3). 


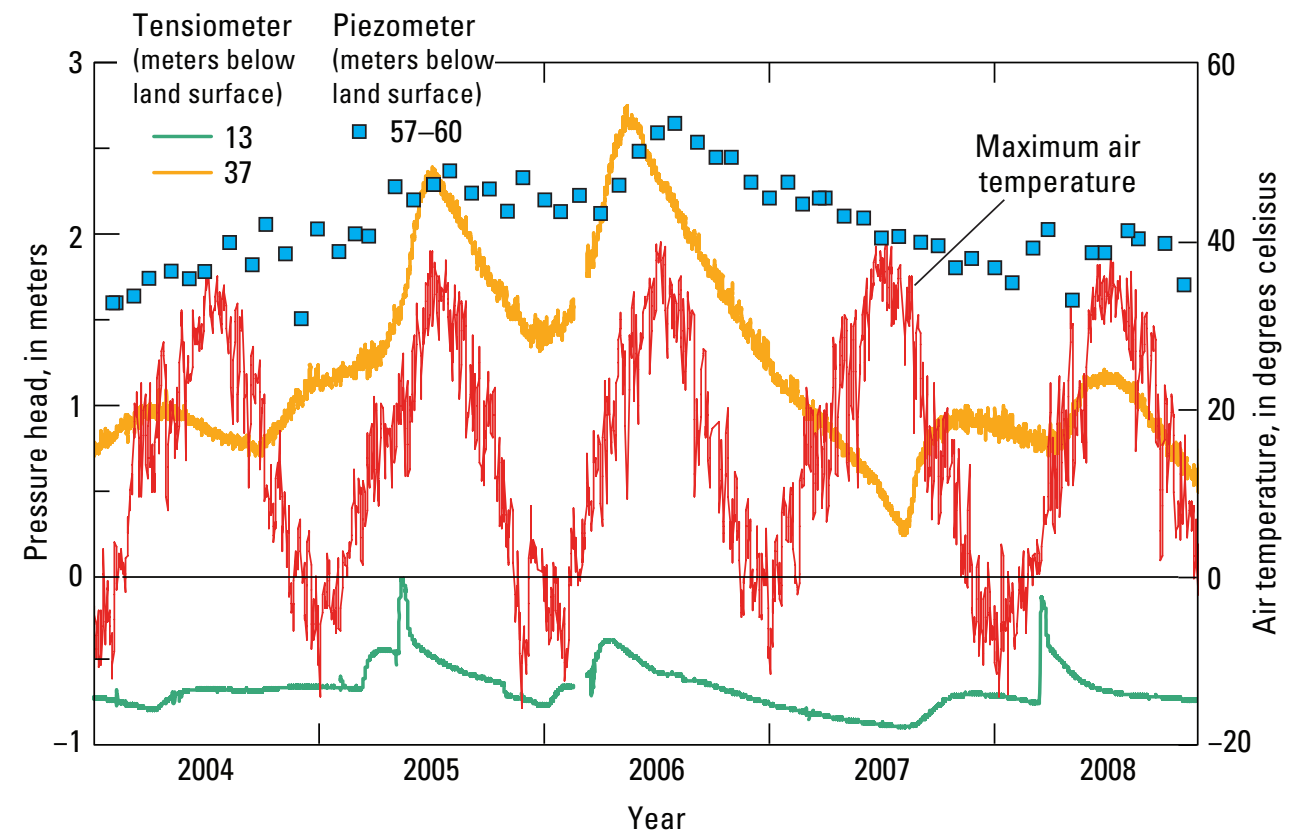

Figure 12. Maximum daily air temperature and the corresponding response to snowmelt in the shallow perched zone at location CS-CH for wetter years 2005 and 2006.

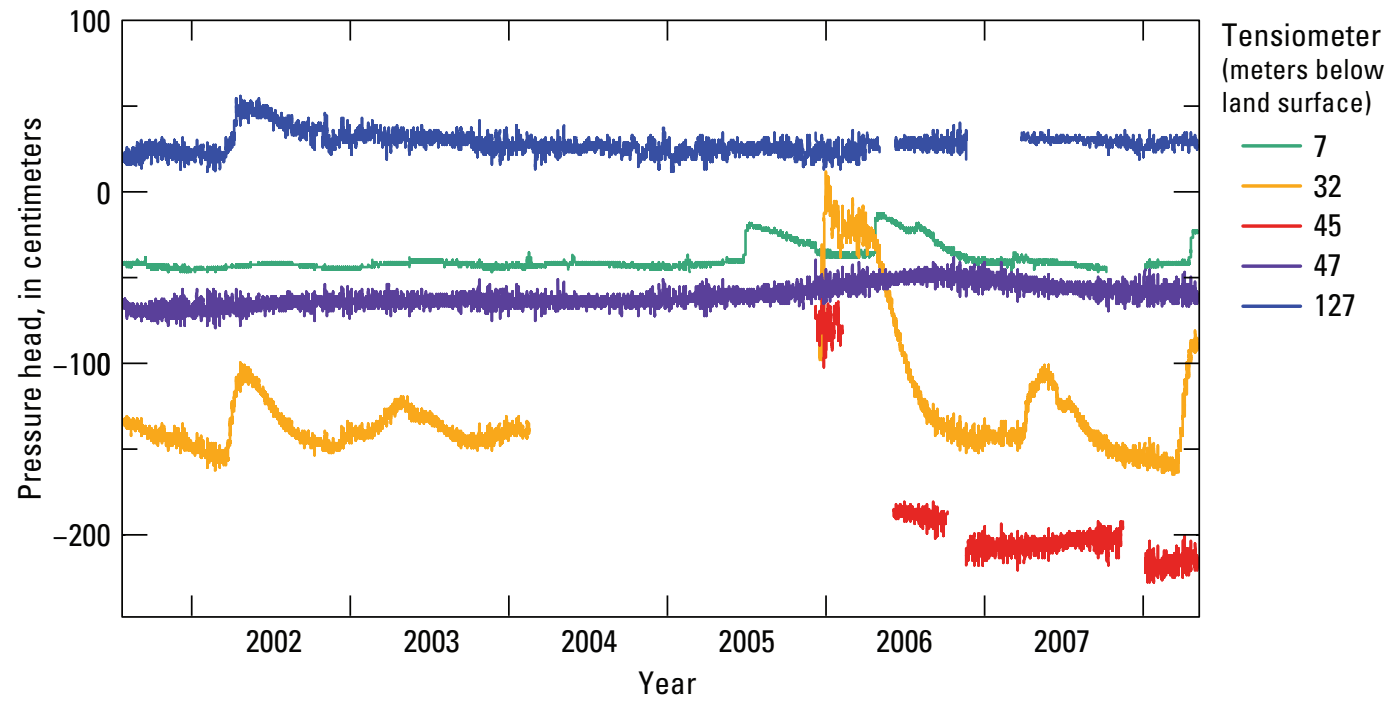

Figure 13. Perched-zone dynamics in the nested tensiometers at location STL (see fig. 3). 
and intermediate perched zones is due to snowmelt, because no flow was recorded in the BLR in 2008 and the rises in 2005 and 2006 both begin before the onset of flow in the BLR. The larger responses in 2005 and 2006 relative to 2008 are related to higher than average annual precipitation and snowmelt (see figs. 5, 6). Although tortuous preferential flow paths are possible, is unlikely that these responses at CS-CH were augmented by flow in the BLR, because no response to BLR flow was observed at $\mathrm{TF}-\mathrm{CH}$ in much closer proximity to the channel (see fig. 3). The staggered response with depth shown in figure 12 illustrates the downward propagation of the wetting front. The lack of response in the tensiometer at $47 \mathrm{~m}$ bls (fig. 11) to snowmelt in 2008 indicates that the response in the intermediate perched zone recorded by the piezometer at $57-60 \mathrm{~m}$ bls may be due to lateral flow along the $\mathrm{B}-\mathrm{C}$ interbed. This suggests that the maintenance of the intermediate perched zone in this location could be due to drainage of the overlying shallow perched zone through discontinuities in the A-B interbed (see fig. $4 A$ ) or connectivity of tortuous preferential flow paths from the BLR channel.

\section{Location STL}

Figure 13 shows the observed records from July 2001 through July 2008 at the STL location for the nested tensiometers at 7, 32, 45, 47, and $127 \mathrm{~m}$ bls. Examination of figure 13 reveals that at this location unsaturated conditions prevail in the shallow and intermediate perched zones; saturated conditions for the tensiometer at $127 \mathrm{~m}$ bls illustrate the persistence of the deep perched zone. During the spring of 2002, the hydrologic response is restricted only to the tensiometers at 32 and $127 \mathrm{~m}$ bls, which suggests that recharge to the deep perched zone follows a combination of vertical preferential flow and lateral flow along the A-B and B-C interbeds (fig. 4). The tensiometer at 7-m depth records minor hydrologic responses in the spring of 2005 and 2006, but the wetting front does not propagate to greater depths within the profile. Although this shallow response closely follows the periods of flow within the $\mathrm{BLR}$, the BLR is approximately $450 \mathrm{~m}$ to the northwest, so the response is likely the result of vertical recharge from snowmelt during these wetter than average years.

\section{Other Locations Without Colocated Tensiometers}

Figure 14 shows the observed records from January 2004 through March 2009 for nine piezometers located throughout the north-central portion of the INTEC facility (fig. 3): 32-2, 33-3, 33-4-1, 37-4, 55-06, MW-2, MW-4-2, MW-5-2, and MW-6. Each piezometer is screened within the shallow perched zone, but none is colocated with a set of nested tensiometers. Examination of figure 14 reveals the gaps in measurement records and the heterogeneous response at the various locations; none of the piezometers exhibit records with hydrologic response correlating clearly to periods of flow in the BLR. Some similarities between the responses in different piezometers are worth noting. The dynamic water level in most of these piezometers (for example 33-2 and MW-4-2) illustrates that multiple sources of recharge are influential at different times of year. Anthropogenic sources of recharge are clearly influential, as illustrated by a rapid decline at 33-4-1 in October 2007 following the repair of fire-control water lines (see also $\mathrm{TF}-\mathrm{CH}$ above) and a similar decline at MW-6 in February 2008 following the repair of a leaky hydrant. Piezometers 55-06 and MW-2 both exhibit sharp increases in

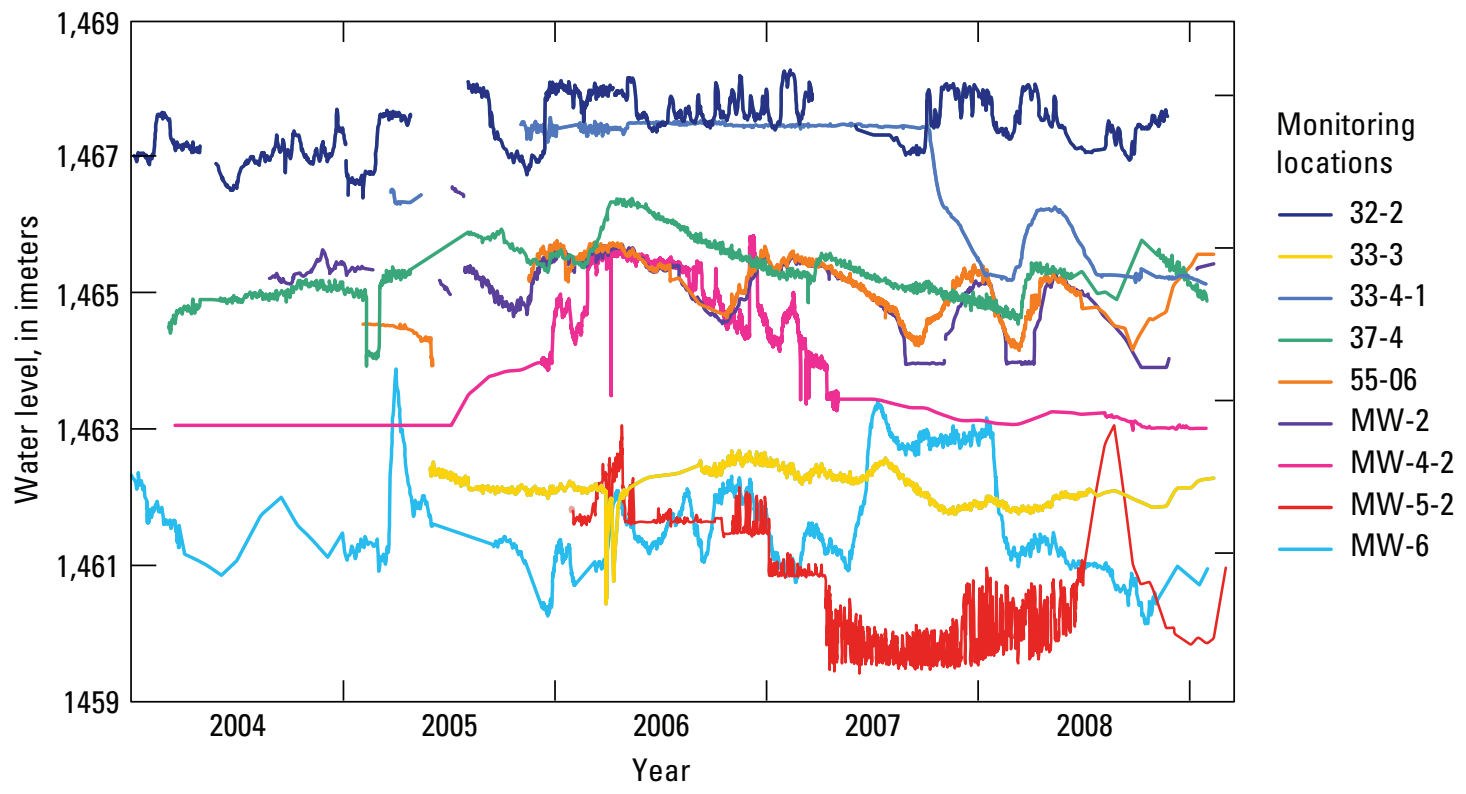

Figure 14. Hydrologic response dynamics in piezometers screened within the shallow perched zone at locations 33-2, 33-3, 33-4-1, 37-4, 55-06, MW-2, MW-4-2, MW-5-2 and MW-6 (see fig. 3). 
mid-winter each year, which has been attributed to anthropogenic discharges to a shallow injection well from a heat pump located in a nearby building along the eastern facility boundary (Jeff Forbes, written commun., 2011). However, 55-06 and MW-2 also exhibit peaks in March of 2006, 2007, and 2008, as do 37-4, 33-4-1, and 33-2 in 2008. These notable increases during the early spring suggest the spring snowmelt is an important factor in the persistence of the shallow perched zone in the north-central portion of INTEC.

\section{Source-Responsive Model}

The source-responsive model was developed (Nimmo, 2007,2010 ) for simulating unsaturated flow processes that are not inherently diffusive, or that do not progress through a series of equilibrium states. The term "source-responsive" reflects the sensitivity of preferential flow to changing conditions at the source of water input (for example, variable rainfall intensity, irrigation, ponding, and runoff). The domain of preferential flow is conceptualized as laminar flow in free-surface films along the walls of pores. Laminar flow theory and several simplifying assumptions allow quantitative estimates of minimum travel times (Nimmo, 2007), or fluxes and volumetric water-content dynamics (Nimmo, 2010). The parsimony of the source-responsive model is advantageous, because it can be applied even when only limited characterization of the subsurface porous media is available. In the work presented here, the SRFM (Nimmo, 2010) is employed heuristically to examine the controls on the variably saturated subsurface dynamics at INTEC and to consider its suitability for future use across INL.

\section{Equations and Simplifying Assumptions}

The complete equations and theoretical development for the SRFM are described elsewhere (Nimmo, 2010). The full SRFM equations provide the framework for combining Richards' equation, to represent diffuse flow processes through the matrix, with source-responsive fluxes to represent preferential flow. Given the low permeability of the basalt matrix at INTEC, the present application of the SRFM assumes that flow through the matrix and domain exchange with the fractures is negligible. As a result, parameterization and evaluation of the model for application at INTEC employs equation 24 from Nimmo (2010), which describes source-responsive fluxes as:

where

$$
q(z, t)=V_{u} L_{u} M(z) f(z, t)
$$

$q$ is the flux density [L T-1],

$z$ is the depth from the surface [L],

$t$ is time [T],

$V_{\mathrm{u}}$ is the characteristic uniform film flow velocity [L T-1],

$V_{\mathrm{u}}$ is the characteristic uniform film thickness [L],

$M$ is the macropore facial area density [L-1], and

$f$ is the active area fraction.
Both the variables $V_{\mathrm{u}}$ and $L_{\mathrm{u}}$ are assumed to be constant at $13 \mathrm{~m} / \mathrm{d}$ and $6 \mu \mathrm{m}$, respectively (see Nimmo, 2007; 2010), leaving the primary degrees of freedom for the model through the parameters $M(z)$ and $f(z, t)$. The facial area density $M$ is a property of the porous medium describing its capacity for transmitting preferential flow, which remains constant in time. The active area fraction $\mathrm{f}$ defines the degree to which the available preferential flow paths are activated and is therefore functionally related to the temporal variability in the availability of water at the source of input.

Certain additional modifications to the equations and simplifying assumptions are necessary for model setup. The observed state variables available for model calibration and evaluation are water levels and hydraulic heads within the shallow perched zone, which effectively represent the integrated response of the unsaturated zone over the vertical profile from the surface. Without information to assess variations in preferential fluxes along the vertical profile $q(z, t)$, source-responsive flux in equation 1 must be integrated over the entire profile at the water-table depth, $z w$ [L], such that variations in $\mathrm{f}$ with depth can be ignored for a given recharge event. As a result, only temporally variable $f(t)$ is considered. Assuming that the region of the profile with the lowest capacity for preferential flow presents the limit to the development of source-responsive flow, the function $M(z)$ can be substituted with a constant $M_{\text {lim }}$ to represent the limiting macropore facial area density for the profile. This allows simplification of equation 1 to calculate fluxes to the water table:

$$
q\left(z_{w}, t\right)=V_{u} L_{u} M_{\lim } f(t)
$$

The basalt at INTEC has a substantially lower permeability in the porous matrix than in the fractures, such that over the time scales relevant to the observations of rapid responses in the shallow perched zone, preferential flow along the connected fractures is the dominant recharge process. The basic formula relating recharge flux to water table describes the accretion rate as:

$$
\frac{d H}{d t}=\frac{q\left(z_{w}, t\right)}{S_{y}}
$$

where

$H$ is the hydraulic head [L], and

$S y$ is the specific yield [-].

In the work presented here, another simplifying assumption is that water-table recession can be attributed to saturated flow laterally through the fractured basalt, as well as percolation vertically through the sedimentary interbeds. Because saturated flow displays diffusive flow behavior, the process of water-table decline can be described using a linear master recession curve:

$$
\frac{d H}{d t}=-\frac{H}{\tau}
$$

where $\tau$ is the master recession constant [T]. 
Assuming the diffuse flow component of the recharge flux is minimal, such that rapid accretion to the perched zone is a result of source-responsive fluxes only, then equation 2 can be substituted into equation 3 and combined with equation 4 to yield an equation for water table fluctuations:

$$
\frac{d H}{d t}=\frac{V_{u} L_{u} M_{\lim } f(t)}{S_{y}}-\frac{H}{t}
$$

Given the initial hydraulic head value $H_{\mathrm{o}}[\mathrm{L}]$, numerical solution of equation 5 through time provides the capability for comparing simulated time-series of hydraulic head to observed subsurface dynamics at BLR-CH in both the piezometer and the tensiometer at $40 \mathrm{~m}$ bls. For the fractured basalts at INTEC, Johnson and others (2002) report a value of $S y$ equal to 0.01 . Regression analysis of observed water levels described in the previous section support the value of about 30 days (700 hours) for $\tau$. The following section describes the methods for parameterizing $f(t)$, calibrating the $M_{\text {lim }}$ value, and evaluating model performance.

\section{Simulating Perched-Zone Dynamics}

In the section on "Data Analysis," the BLR was identified as an intermittent source of recharge to the perched zones at monitoring location BLR-CH, with direct contributions to the upper perched zone and indirect or delayed contributions to the middle perched zone. The parameterization of $f(t)$ therefore employs transmission losses along the BLR observed between the two USGS gaging stations at Lincoln Boulevard (see fig. 2) and $15 \mathrm{~km}$ upstream at the INL Diversion. The time series of observed discharge at the two locations (fig. 7) suggests that the magnitude of transmission losses is greatest during periods of high discharge, which is also apparent in the subsurface hydrologic response (fig. 9). The time series of total transmission losses for the $15-\mathrm{km}$ reach of the BLR were therefore used to define a simple, discharge-dependent step function for $f(t)$ whenever flow occurs in the BLR at the Lincoln Boulevard gaging station:

$$
\begin{aligned}
& \text { If } q_{\text {loss }}(t)=0 \text {, then } f(t)=0 \\
& \text { If } 0<q_{\text {loss }}(t)<1 \mathrm{~m}^{3} \mathrm{~s}^{-1} \text {, then } f(t)=0.5 \\
& \text { If } q_{\text {loss }}(t)>1 \mathrm{~m}^{3} \mathrm{~s}^{-1} \text {, then } f(t)=1.0
\end{aligned}
$$

Figure 15 illustrates the time series for transmission losses for the $15-\mathrm{km}$ reach (calculated as the difference between the discharge records from the two USGS gages shown in figure 7) and the active area fraction calculated using this step function for the period between 2005 and 2006.

Using the observed initial head value, equation 5 was solved using a forward finite-difference scheme with a daily time step. The value of $M_{\lim }$ was calibrated to best fit observed dynamics in the shallow piezometer and tensiometer at BLR$\mathrm{CH}$ for the event beginning in April 2006 (fig. 16A). Using a classic split-sample approach (Klemes, 1986), the model parameterization with the calibrated $M_{\lim }$ value of $60 \mathrm{~m}^{-1}$ was evaluated against the observed response in the same piezometer and tensiometer pair for the event beginning in May of 2005 (fig. 16B). Table 1 summarizes the model performance for the calibration and evaluation events using several well-known model performance statistics. The time series of simulated and observed hydraulic head for the BLR-CH tensiometer and piezometer in the shallow perched zone shown in figure 16 and the performance statistics in table 1 illustrate the reasonably good

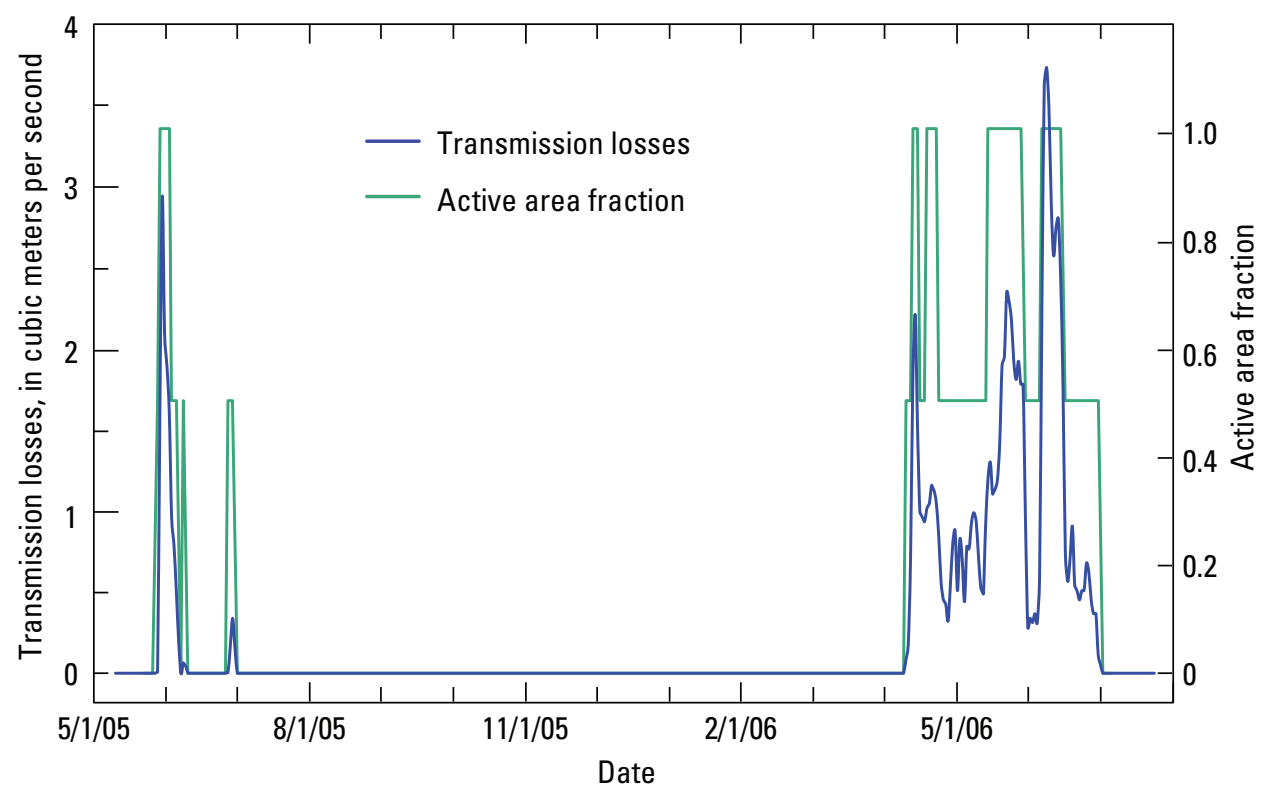

Figure 15. Transmission losses along the 15-km reach of the Big Lost River between the two gaging stations in figure 7 and the time series for active area fraction $f(t)$ employed in the source-responsive model. 

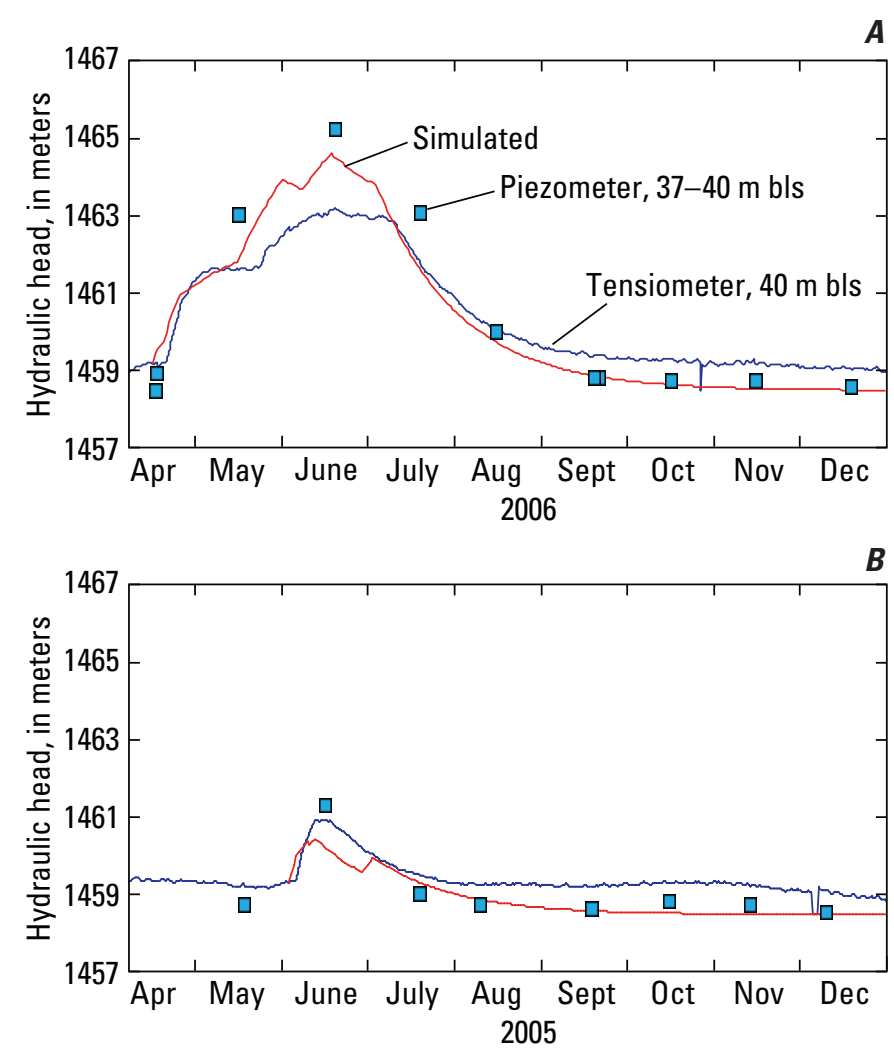

Figure 16. Observed time series of hydraulic head for the tensiometer and piezometer at BLR-CH with simulated hydraulic heads for two events: $(A)$ model calibration between April 8, 2006, and January 1, 2007, and $(B)$ model performance evaluation between April 8, 2005, and January 1, 2006.

Table 1. Model performance statistics calculated for the calibration and evaluation period using observed responses from both the tensiometer and piezometer in the shallow perched zone at BLR-CH.

\begin{tabular}{lcc}
\hline \multicolumn{1}{c}{ Simulation Period } & \multicolumn{2}{c}{ Model Performance Statistic } \\
\cline { 2 - 3 } & $\begin{array}{c}\text { Root Mean } \\
\text { Square Error }{ }^{1}\end{array}$ & $\begin{array}{c}\text { Nash and Sutcliffe } \\
\text { Error Function }{ }^{2}\end{array}$ \\
\hline $\begin{array}{l}\text { Calibration Event } \\
(4 / 16 / 2006-12 / 18 / 2006)\end{array}$ & 0.62 & 0.93 \\
Piezometer & 0.68 & 0.78 \\
Tensiometer & 0.33 & 0.80 \\
\hline $\begin{array}{l}\text { Evaluation Event } \\
(5 / 30 / 2005-1 / 16 / 2006) \\
\text { Piezometer } \\
\text { Tensiometer }\end{array}$ & 0.60 & -0.53 \\
\hline${ }^{1}$ Root Mean Square Error, RMSE $=\sqrt{\frac{\sum_{\mathrm{i}=1}^{\mathrm{n}}\left(\mathrm{O}_{\mathrm{i}}-\mathrm{P}_{\mathrm{i}}\right)^{2}}{\mathrm{n}}}$ \\
${ }^{2}$ Nash and Sutcliffe Error Function, $\mathrm{EF}=\frac{\left[\sum_{\mathrm{i}=1}^{\mathrm{n}}\left(\mathrm{O}_{\mathrm{i}}-\overline{\mathrm{O}}\right)^{2}\right]-\left[\sum_{\mathrm{i}=1}^{\mathrm{n}}\left(\mathrm{P}_{\mathrm{i}}-\mathrm{O}_{\mathrm{i}}\right)^{2}\right]}{\left[\sum_{\mathrm{i}=1}^{\mathrm{n}}\left(\mathrm{O}_{\mathrm{i}}-\overline{\mathrm{O}}\right)^{2}\right]}$
\end{tabular}

model performance. The difference between measured response in the piezometer (screened at $37-40 \mathrm{mbls}$ ) and tensiometer (40 $\mathrm{m}$ bls) at BLR-CH is reflected in the differences in model performance statistics for each type of observation (table 1). These differences may be in part the result of uncertainty associated with tensiometer measurements in fractured rock (Finsterle and Faybishenko, 1999).

\section{Discussion}

The simulated and observed dynamics in BLR-CH clearly show the importance of BLR transmission losses in controlling the shallow, intermediate, and deeper perchedzone dynamics within $150 \mathrm{~m}$ of the BLR channel. The lack of shallow perched-zone response to BLR flow at TF-CH and other monitoring locations even farther away from the channel suggests that, at distances of $300 \mathrm{~m}$ or greater from the BLR, snowmelt is more important for recharge to the shallow perched zone than BLR transmission losses. However, the relative importance of BLR flow on maintaining the intermediate and deeper perched zones beneath INTEC remains unclear. The magnitudes of the perched-zone response to BLR transmission losses are between 3 and $6 \mathrm{~m}$ at $150-\mathrm{m}$ distance from the channel, whereas the response to snowmelt recharge is generally between 0.5 and $2 \mathrm{~m}$. It is plausible that the shallow perched-zone response to snowmelt occurs directly below the source of recharge. In contrast, the subsurface response to BLR flow directly below the channel is unknown and potentially substantially larger than the observed response at BLR$\mathrm{CH}$. The substantial difference in magnitude between these two types of responses suggests that the importance of contributions from flow in the BLR to perched saturation throughout INTEC cannot be ruled out, particularly at greater depths.

The analysis presented herein highlights the role of lateral saturated flow above sedimentary interbeds in maintaining the intermediate and deeper perched zones. However, it is unclear whether the dampened responses with depth observed at $\mathrm{BLR}-\mathrm{CH}$ and $\mathrm{CS}-\mathrm{CH}$ are a result of drainage of the perched saturated zones via lateral flow along the interbeds (see fig. $4 A$ ) or whether some vertical flow through the sedimentary interbeds also contributes to perched saturation at depths (see fig. $4 B$ ). In some locations there is a clear downward propagation of recharge and drainage (for example, BLR-CH and CS-CH), whereas in other locations the shallow and intermediate zones are clearly decoupled (for example, TF_CH). The lateral extent of the zones of perched saturation is unclear-at some locations there is no intermediate perched zone (for example, STL), whereas at others there appears to be no shallow or deep perched zone (for example, TF-CH). Further characterization of the lateral extent of the interbeds and horizontal fluxes is therefore needed to understand complex flow pathways within the variably saturated subsurface below INTEC.

One particularly important finding of this work is that source-responsive preferential flow through the fractured 
basalt is a plausible mechanism for vertical transport of water and contaminants. The well-constrained timing and magnitude of transmission losses in the BLR, in combination with resulting hydrologic response observations in the shallow perched zone, facilitated a test of the utility of the SRFM for quantifying preferential flow at INTEC. The simplified application of the SRFM captures the subsurface dynamics very well for the calibration event and reasonably well for the evaluation event (table 1). The poorer model performance for the evaluation event may be related to the smaller magnitude of the source (that is, discharge in the BLR) and response (that is, rise in the shallow perched zone). The error reflects a higher degree of uncertainty in the nature of the discharge threshold for active area fraction. With a greater number of events for calibration and evaluation a more robust relation between transmission losses and active area fraction could be established. Regardless, the suitability of the discharge threshold for subsurface response shown herein may partially explain previous reports of poor performance of a simple model for transmission losses calculated using a linear function of discharge for the BLR (Baker and others, 2004). The threshold discharge could be related to water abstraction from the surrounding matrix material, which must be satisfied before preferential flow can penetrate to the depth of the A-B interbed. The threshold may also reflect the conditions under which the BLR loses water from the banks versus the streambed alone.

For both calibration and evaluation events the SRFMsimulated hydrologic response begins before the actual observed response in the shallow perched zone, which reflects two major simplifying assumptions related to the vertical and lateral travel times in the variably saturated subsurface. The first assumption is the application of a uniform active area fraction with depth over some unconstrained length of the BLR channel. This assumption may be problematic because it ignores the vertical travel time along the $36-\mathrm{m}$ profile between the BLR channel and the underlying perched zone, as well as lateral variations along the channel. The second assumption is that the lateral travel time is negligible between the arrival of the wetting front at the shallow perched zone and the response at BLR-CH nearly $150 \mathrm{~m}$ to the south. The lateral movement of water along the interbed may also result in a damping of the accretion to the perched zone observed at the BLR-CH monitoring location relative to the actual accretion directly below the BLR channel. The relatively symmetrical rising and falling limbs of the well hydrographs (for example, fig. 11) may be a reflection of such lateral damping, which is a potential source of uncertainty in the calibrated $M_{\lim }$ value.

Improvements of the SRFM to establish methods for assigning spatially and temporally variable $f(t)$ values are ongoing. Lateral fluxes along sedimentary interbeds could be accounted for using the groundwater flow equation if some estimates of the lateral saturated hydraulic conductivity and the hydraulic head gradients in the shallow perched zones were available. It should also be noted that the influence of surficial sediments along the channel bed are ignored in the present application.
Quantitative characterization of the timing and magnitude of recharge from snowmelt is needed to test the applicability of the SRFM for simulating recharge in other locations throughout INTEC. However, the SRFM could be applied using the calibrated $M_{\text {lim }}$ values and the simplified model setup employed herein to provide estimates of $f(t)$ through calibration against observed hydrologic response in the shallow perched zones at CS-CH, 33-4-1, 37-4, 55-06, and MW-5-2. These inverse-estimated time series of active area fraction could provide some additional quantitative insights into the timing and relative magnitude of snowmelt in relation to temperature and precipitation records, which could in turn be compared to simple energy balance modeling. For example, an inverse-estimated $f(t)$ could be used to assess the importance of rain-on-snow events for recharge to the shallow perched zones. The value of $M_{\text {lim }}$ is unlikely to be a universal characteristic of the fractured basalt throughout INTEC, so the $f(t)$ estimated using $M_{\lim }=60 \mathrm{~m}^{-1}$ (calibrated on the basis of local information at BLR-CH) would be influenced by uncertainty in this effective $M_{\text {lim }}$ values at other locations. Further application of SRFM for simulating snowmelt conditions is also complicated by the anthropogenic influence associated with snow removal to concentrated areas.

Overall, the reasonably good model performance suggests that the SRFM could be a useful tool for improving quantitative characterization of contaminant transport through the vertically connected fracture network of the basaltic units. Although there is insufficient information to explicitly simulate matrix-fracture interactions and contaminant transport, the calibrated SRFM could be applied to assessing fluxes via advection only, with no sorption or diffusion. Estimates based on advection only would provide a more conservative assessment of the worst-case scenarios than an approach based entirely on traditional diffusive flow processes.

The recent Record of Decision (ROD) (Department of Energy, 2007b) dictates several changes in operations at INL, including: (1) prohibits use of the portion of the ESRP Aquifer in the vicinity of INTEC and restricts drilling through the perched zones, (2) plans to limit recharge by installing low-permeability pavement over the recharge control zone and diverting runoff from these areas along lined drainage ditches into evaporation ponds off-site, and (3) requires implementation and maintenance of additional recharge controls in the northern portion of INTEC to reduce recharge from anthropogenic and storm water to the perched zones. The ROD also states that lining of the adjacent reach of the BLR may be necessary to reduce perched saturation (Department of Energy, 2007b). Relative to the mandates of the ROD, the results reported here support the idea that limiting transmission losses in the BLR would reduce the perched zones in the immediate vicinity of the channel. However, further characterization of lateral fluxes along the sedimentary interbeds and consideration of how the perched zones drain is needed for a comprehensive assessment of the controls on perched saturation below INTEC. For example, the analysis of observations at BLR-CH demonstrates that episodic discharge in the BLR 
can sustain perched saturation in the shallow, intermediate, and deeper perched zones. It is possible that more gradual, sustained releases to the BLR or lining the channel with an impermeable bed could complement ongoing strategies (that is, paving surfaces and lining drainage ditches) to reduce perched-zone recharge across the northern portion of INTEC. Given the contributions of snowmelt and anthropogenic recharge to the perched zones, completely eliminating the perched zones at INTEC seems unlikely (Jeff Forbes, written commun., 2011).

\section{Summary}

Overall, the analysis presented herein confirms that influx of water from the annual spring thaw and precipitation exerts the strongest influences on the shallow perched zones underlying the northern portion of the INTEC facility. Results from this study indicate that flow within the BLR contributes episodic recharge pulses to the shallow, intermediate, and deeper perched zones at least $150 \mathrm{~m}$ from the channel, but that the shallow perched zone is not influenced by transmission losses at distances of $300 \mathrm{~m}$ or more from the channel. It is difficult to determine the influence of BLR transmission losses on the intermediate and deeper perched zones at distances greater than $150 \mathrm{~m}$ from the channel with the available hydrologic response data. Regardless, our analysis suggests that ongoing efforts to eliminate all anthropogenic sources of recharge (Department of Energy, 2007b) cannot be expected to eliminate the persistence of all the perched saturated zones underneath the northern portion of INTEC. Further information is needed to quantify the importance of lateral flow along the sedimentary interbeds and drainage of the shallow perched zone to understand controls on the intermediate and deeper perched zones beneath INTEC.

The analysis of observed records of streamflow, temperature, and subsurface hydrologic response identified a limited range of data for adequately testing the SRFM. The onset of spring snowmelt can be approximated with temperature records, but the relative magnitude of this recharge source is not well constrained. The USGS discharge records for the BLR provide quantitative estimates of transmission losses that are appropriate for parameterizing the SRFM. The monitoring of perched-zone dynamics at BLR-CH provided the observational records for calibration and evaluation of a simplified formulation of the SRFM. The simulation results compare reasonably well with measured perched-zone dynamics, which suggests that the SRFM is an appropriate tool for quantifying rapid preferential flow along connected fracture networks within the basalt units underlying INTEC. Some simplifications used for the present application of the SRFM could be adjusted to improve model performance. In particular, the implicit assumption of instantaneous response associated with the spatially uniform active area fraction along the entire depth profile should be improved upon in future applications of the SRFM.

The simulation results presented here can be useful for improving quantitative characterization of contaminant transport in the complex vadose zone beneath INTEC. For example, estimates of recharge fluxes via source-responsive flow could provide a worst-case estimate of contaminant transport via advective fluxes. While the focus of this effort was motivated by the known groundwater contamination associated with activities at INTEC, the implications of this work are useful for addressing similar environmental concerns across the INL. The methods employed here could also be useful in analogous hydrogeologic settings involving rapid fluxes through variably saturated fractured bedrock systems.

\section{Acknowledgments}

The authors would like to thank Jeff Forbes of CH2M Hill (Idaho Cleanup Project) for providing the piezometer and tensiometer data used in this study.

\section{References Cited}

Anderson, S.R., 1991, Stratigraphy of the unsaturated zone and uppermost part of the Snake River Plain aquifer at the Idaho Chemical Processing Plant and Test Reactor Area, Idaho National Engineering Laboratory, Idaho: U.S. Geological Survey Water-Resources Investigations Report, 91-4010 (Department of Energy, ID-22095), 71 p.

Anderson, S.R., Lisewski, M.J., and Ackerman, D.J., 1996, Thickness of surficial sediment at and near the Idaho National Engineering Laboratory, Idaho: U.S. Geological Survey Open-File Report 96-330 (DOE/ID-22128), 16 p.

Baker, K., Hull, L., Bennett, J., Ansley, S., and Heath, G., 2004, Conceptual models of flow through a heterogeneous layered vadose zone under a percolation pond, Idaho National Engineering and Environmental Laboratory: INEEL/EXT-04-01679.

Barraclough, J.T., Teasdale, W.E., and Jensen, R.G., 1967, Hydrology of the National Reactor Testing Station area, Idaho-Annual progress report, 1965: U.S. Geological Survey Open-File Report IDO-22048, 107 p.

Bartholomay, R.C., 2009, Iodine-129 in the Snake River Plain aquifer at and near the Idaho National Laboratory, Idaho, 2003 and 2007: U.S. Geological Survey Scientific Investigations Report 2009-5088, 28 p. 
Bennett, C.M., 1990. Streamflow losses and ground-water level changes along the Big Lost River at the Idaho National Engineering Laboratory, Idaho U.S. Geological Survey Water Resources Investigation Report 90-4067, p. 49.

Davis, L.C., 2010. An update of hydrologic conditions and distribution of selected constituents in water, Snake River Plain aquifer and perched groundwater zones, Idaho National Laboratory, Idaho, emphasis 2006-08: U.S. Geological Survey Scientific Investigations Report 2010-5197 (DOE/ ID-22212), $80 \mathrm{p}$.

Department of Energy, 1989, Climatography of the Idaho National Engineering Laboratory, DOE/ID-12118, Rev. 0: U.S. Department of Energy Idaho Operations Office, December, 1989.

Department of Energy, 2004, Long-Term Monitoring Plan for Operable Unit 3-13, Group 5, Snake River Plain Aquifer, DOE/ID-10783, Rev. 3: U.S. Department of Energy Idaho Operations Office, August, 2004.

Department of Energy, 2005a, Long-Term Monitoring Plan for Operable Unit 3-13, Group 4, Perched Water, DOE/ ID-10746, Rev. 2: U.S. Department of Energy Idaho Operations Office, November, 2005.

Department of Energy, 2005b, Monitoring System and Installation Plan for Operable Unit 3-13, Group 4, Perched Water, DOE/ID-10774, Rev. 3: U.S. Department of Energy Idaho Operations Office, January, 2005.

Department of Energy, 2005c, INTEC Water Balance Report for Operable Unit 3-13, Group 4, Perched Water, DOE/ ID-11248, Rev. 0: U.S. Department of Energy Idaho Operations Office, November, 2005.

Department of Energy, 2005d, Geochemical Study for Perched Water Source Identification at INTEC, Engineering Design File, DOE/ID-EDF-5758, Rev. 0: U.S., Department of Energy Idaho Operations Office, May, 2005.

Department of Energy, 2006, Annual INTEC water monitoring report for Group 4-Perched water (2005), DOE/ID-11259, Rev. 0: U.S. Department of Energy Idaho Operations Office, January, 2006.

Department of Energy, 2007a, INTEC groundwater monitoring report (2006) DOE/ID-11301 Rev. 0: U.S. Department of Energy Idaho Operations Office, February, 2007.

Department of Energy, 2007b, Record of decision for tank farm soil and INTEC groundwater, DOE-ID 11296, Rev. 0: U.S. Department of Energy Idaho Operations Office, May, 2007.

Department of Energy, 2007c, Monitoring report/decision summary for operable unit 3-13, Group 4, perched water, DOE/ID-11326, Rev. 0: U.S. Department of Energy Idaho Operations Office, October, 2007.
Department of Energy, 2011, Fiscal year 2010 annual report for operable unit 3-14, tank farm soil and INTEC groundwater, DOE/ID-11442, Rev. 0: U.S. Department of Energy Idaho Operations Office, May 2011.

Finsterle, S., and Faybishenko, B., 1999, What does a tensiometer measure in fractured rock?, in van Genuchten, M.T., Leiij, J.J., and Wu, L., eds., Proceedings of the International Workshop on Characterization and Measurement of the Hydraulic Properties of Unsaturated Porous Media: U.S. Salinity Lab., Riverside, Calif., p. 867-875.

Hackett, B., Pelton, J., and Brockway, C., 1986, Geohydrologic story of the eastern Snake River Plain and the Idaho National Engineering Laboratory: U.S. Department of Energy, Idaho Operations Office, Idaho National Engineering Laboratory, $32 \mathrm{p}$.

Johnson, G.S., Frederick, D.B., and Cosgrove, D.M., 2002, Evaluation of a pumping test of the Snake River Plain aquifer using axial-flow numerical modeling: Hydrogeology Journal, v. 10 , p. 428-437, DOI 10.1007/s10040-002-0201-0.

Klemes, V., 1986, Operational testing of hydrological simulation models: Hydrological Sciences Journal, v. 31, no. 1, p. 13-24.

Nimmo, J.R., 2007, Simple predictions of maximum transport rate in unsaturated soil and rock: Water Resources Research, v. 43, W05426, doi:10.1029/2006WR005372.

Nimmo, J.R., 2010, Theory for source-responsive and freesurface film modeling of unsaturated flow: Vadose Zone Journal, v. 9, no. 2, p. 295-306.

Nimmo, J.R., Perkins, K.S., Rose, P.A., Rousseau, J.P., Orr, B.R., Twining, B.V., and Anderson S.R., 2002, Kilometerscale rapid transport of naphthalene sulfonate tracer in the unsaturated zone at the Idaho National Engineering and Environmental Laboratory: Vadose Zone Journal, v. 1, p. 89-101.

Perkins, K.S., 2003, Measurement of sedimentary interbed hydraulic properties and their hydrologic influence near the Idaho Nuclear Engineering and Technology Center at the Idaho National Engineering and Environmental Laboratory: U.S. Geological Survey Water-Resources Investigations Report 03-4048, 19 p.

Perkins, K.S., 2008, Laboratory-measured and property-transfer modeled saturated hydraulic conductivity of Snake River Plain Aquifer Sediments at the Idaho National Laboratory, Idaho: U.S. Geological Survey Scientific Investigations Report 2008-5169, 13 p. 
Perkins, K.S., and Nimmo, J.R., 2000, Measurement of hydraulic properties of the B-C interbed and their influence on contaminant transport in the unsaturated zone at the Idaho National Engineering and Environmental Laboratory: U.S. Geological Survey Water-Resources Investigations Report 00-4073, 30p.

Perkins, K.S., and Winfield, K.A., 2007, Property transfer modeling to estimate unsaturated hydraulic conductivity of deep sediments at the Idaho National Laboratory, Idaho: U.S. Geological Survey Scientific Investigations Report 2007-5093, $22 \mathrm{p}$.

Winfield, K.A., 2003, Spatial variability of sedimentary interbed properties near the Idaho Nuclear Technology and Engineering Center at the Idaho National Engineering and Environmental Laboratory, Idaho: U.S. Geological Survey Water-Resources Investigations Report 03-4142, 36 p.

Winfield, K.A., 2005, Development of property-transfer models for estimating the hydraulic properties of deep sediments at the Idaho National Engineering and Environmental Laboratory, Idaho: U.S. Geological Survey Scientific Investigations Report 2005-5114, 49 p. 
Publishing support provided by the U.S. Geological Survey Publishing Network, Menlo Park Publishing Service Center, California Manuscript approved for publication, December 1, 2011

Edited by Peter H. Stauffer

Layout by David R. Jones

For more information concerning the research in this report, contact the Director, Idaho Water Science Center

U.S. Geological Survey

230 Collins Road

Boise, Idaho 83702

http://id.water.usgs.gov 
